\title{
TWO NEW SPECIES OF ATLANTIC TROUT (ACTINOPTERYGII, SALMONIDAE) FROM MOROCCO
}

\author{
Ignacio Doadrio ${ }^{1 *}$, Silvia Perea ${ }^{1} \&$ Ahmed Yahyaoui ${ }^{2}$ \\ 'Biodiversity and Evolutionary Group. Museo Nacional de Ciencias Naturales. \\ CSIC. C/José Gutiérrez Abascal, 2. 28006. Madrid. Spain \\ ID: urn:Isid:zoobank.org:author:1514FE9E-2AA2-46D1-BB43-51F5E8EF1566 \\ SP: urn:Isid:zoobank.org:author:75C3112F-5BE9-4512-A9DB-DDA2A10497C7 \\ ${ }^{2}$ Laboratory of Zoology and General Biology, Faculty of Sciences, Mohammed V. University. B.P. 1014. Rabat. Morocco \\ urn:Isid:zoobank.org:author:EA344560-EOFA-4D5D-A51C-23771D124D4B \\ * Corresponding author: doadrio@mncn.csic.es
}

\begin{abstract}
Four trout species of the genus Salmo Linnaeus, 1758 have been traditionally recognized in Morocco: S. macrostigma Duméril, 1858; S. pallaryi Pellegrin, 1924; S. pellegrini Werner, 1931 and S. akairos Delling \& Doadrio, 2005. Two of these species are mainly distributed in Mediterranean (S. macrostigma) and Atlantic (S. pellegrini) river basins while the other two species are restricted to isolated lakes in the Atlas Mountains, one of them to Ifni Lake (S. akairos) and the other, probably extinct, to Sidi Ali Lake (S. pallaryi). Preliminary phylogenetic and regional studies based on molecular data have found high structuration of the populations of this genus in Morocco. These studies focused on allozymes, microsatellites and mitochondrial markers found genetic differences in populations from Isli Lake (Atlas Mountains) and the Draa Basin in southern Morocco. In this work we provide different morphological and genetic traits to distinguish these populations from Isli Lake and Draa Basin as two different species.
\end{abstract}

urn:Isid:zoobank.org:pub:131DCCC9-5D2D-40B9-8F53-A2DAFA1AAB45

Key words: Draa Basin; Isli Lake; Morocco; Salmonidae; New species; Taxonomy.

\section{RESUMEN}

\section{Dos nuevas especies de truchas atlánticas (Actinopterygii, Salmonidae) de Marruecos}

Cuatro especies del género Salmo Linnaeus, 1758 se han reconocido tradicionalmente en Marruecos: $S$. macrostigma Duméril, 1858; S. pallaryi Pellegrin, 1924; S. pellegrini Werner, 1931 y S. akairos Delling y Doadrio, 2005. Dos de estas especies se distribuyen por las cuencas mediterráneas (S. macrostigma) y atlánticas (S. pellegrini), mientras que las otras dos están restringidas a lagos aislados en las montañas del Atlas, una de ellas al Lago Ifni (S. akairos) y la otra, probablemente extinta, al Lago de Sidi Alí (S. pallaryi). Estudios filogenéticos preliminares y estudios regionales basados en alozimas, microsatélites y marcadores mitocondriales hallaron una alta estructuración de las poblaciones de este género en Marruecos, con diferencias genéticas significativas en las poblaciones del lago de Isli (Montañas del Atlas) y de la cuenca del Draa en el sur de Marruecos. En el presente trabajo nosotros proveemos evidencia morfológica y genética para distinguir estas poblaciones del lago de Isli y de la cuenca del Draa como dos especies diferentes.

Palabras clave: Cuenca del Draa; Lago de Isli; Marruecos; Salmonidae; nuevas especies; Taxonomía.

Recibido/Received: 16/06/2015; Aceptado/Accepted: 15/07/2015; Publicado en línea/Published online: 19/08/2015

Cómo citar este artículo/Citation: Doadrio, l., Perea, S. \& Yahyaoui, A. 2015. Two new species of Atlantic trout (Actinopterygii, Salmonidae) from Morocco. Grae/lsia, 71(2): e031. http://dx.doi.org/10.3989/graellsia.2015.v71.142

Copyright: (C) 2015 SAM y CSIC. Salvo indicación contraria, todos los contenidos de la edición electrónica de Grael/sia se distribuyen bajo licencia de uso y distribución Creative Commons Reconocimiento no Comercial 3.0. España (cc-by-nc). 


\section{Introduction}

Salmonid fishes constitute a monophyletic clade that is composed of three main lineages, namely coregonins, thymallins and salmonins. These three lineages are widely spread in cold waters of the northern hemisphere (Shedko et al., 2013). Within salmonids, the taxonomy of trouts (Salmo spp.) is controversial because of their high phenotypic variation in contrast to the scarce genotypic differentiation between populations, occurring in an extensive original distribution in the mountains of Eurasia and North Africa. This disagreement between morphological and genetic studies has led to different taxonomic approaches. Molecular studies usually prefer the use of lineages within Salmo trutta Linnaeus, 1758 to refer to different geographical populations (Machordom et al., 2000; Bernatchez, 2001; Suárez et al., 2001; Cortey et al., 2004). In contrast, in recent years, morphological studies prefer to fragment $S$. trutta into different species, using the traditional morphological species concept with a phylogenetic argument based on the data provided by molecular studies (Delling, 2003; Kottelat \& Freyhof, 2007).

For this reason, several species have been recently described from the periphery of distribution of genus Salmo around the Mediterranean region (Delling, 2010; Turan et al., 2010, 2011, 2012, 2014a, 2014b) and also in northern Africa, where a new dwarf species was described from Ifni Lake (Salmo akairos Delling \& Doadrio, 2005). This latter species inhabits an isolated lake in the Atlas Mountains, presenting differences in morphological traits but scarce genetic differentiation with respect to other Atlantic lineages of S. trutta (Suárez et al., 2001; Delling \& Doadrio, 2005; Snoj et al., 2011). Therefore, in northern Africa five species of genus Salmo have been described so far (S. macrostigma Duméril, 1858; S. lapasseti Zill, 1858; S. pallaryi Pellegrin, 1924; S. pellegrini Werner, 1931 and $S$. akairos). The species $S$. lapasseti from Algeria is considered to be a synonym of $S$. macrostigma (Delling \& Doadrio, 2005). Therefore, four species are currently recognized in North Africa.

In contrast to other NorthAfrican countries, Morocco preserves natural populations of trout and three of the four currently recognized species in North Africa are present in the country: S. macrostigma, S. pellegrini and $S$. akairos. The species $S$. pallaryi was described from Sidi Ali Lake, in the Middle Atlas Mountains (Morocco), but the autochthonous population of the lake seem to have disappeared due to the introduction of exotic species. Nevertheless, some authors consider that the population from Isli Lake could belong to S. pallaryi (Schöffmann, 1993; Delling, 2003).

The current taxonomy of Moroccan trout recognizes one species distributed in the Atlantic basins ( $S$. pellegrini); one species from the Mediterranean basins (S. macrostigma); another species confined to Ifni Lake in the Souss basin (S. akairos) and the uncertain taxonomic position of the Isli Lake population. The main aims of this study are to clarify the taxonomic position of the Isli trout population and to characterize morphologically, for the first time, the populations from the Draa basin (located in southern Moroccan Atlas). Consequently we describe two new species of genus Salmo Linnaeus, 1758.

\section{Material and Methods}

The description of two new species of genus Salmo in Morocco was based on 35 individuals from the Dades River, Draa basin, Ait Aatou O’Moussa (31.871776, -5.738205), Morocco (Voucher numbers: MNCN 290751-290785) and 20 individuals from Isli Lake, Imilchil (32.217526, -5.548031), Morocco (Voucher numbers: MNCN 280413-280414; 281050-281067). For comparative purposes, we analysed also the different trout populations from North Africa detailed in Delling \& Doadrio (2005). In addition to this material we included 18 adult individuals from the $\mathrm{Ziz}$ River, Ziz basin, Zaouia Sidi Hamza, (32.433030, -4.715145), Morocco (Voucher numbers: MNCN 290732-290749), 14 individuals from the Miaami Lagoon, Oum er Rbia Basin, Douar Khamlich (32.8985, -5.375966), Morocco (Voucher numbers: MNCN 280035-280045, MNCN 279000-279002), 13 individuals from Assif Melloul, Oum er Rbia Basin, Agoudal, (32.033595, -5.4694132), Morocco (Voucher numbers: MNCN 281068-281080), 8 individuals from Assif Melloul, Oum er Rbia Basin, Imilchil (32.151130, -5.619814), Morocco, (Voucher numbers: MNCN 115047-053, MNCN 115055), 16 individuals from Lakhdar River, Oum er Rbia Basin Aït Bou Oulli (31.604651, -6.597173) Morocco (Voucher numbers: MNCN 290623-290638), 10 individuals from Lakhdar River, Oum er Rbia Basin, Agouti (31.637684, -6.480359), Morocco (Voucher numbers: MNCN 290785-290794), 7 individuals from Ifni Lake, Aït Igran (31.030532, -7.884218), Morocco, (Voucher numbers: MNCN 281081-281087), 12 individuals from Ikiss River, Moulouya Basin, Tattiouine (32.58228, -4.76718), Morocco (Voucher numbers: MNCN 290797-290808) and 11 individuals from Imlil River, Tensift Basin, Douar Armed (31.125006, -7.919222), Morocco, (Voucher numbers: MNCN 290817-290827). These populations are geographically represented in Fig. 1.

Twenty-six morphometric measurements and ten meristic variables were recorded for all specimens. All morphometric measurements were in millimetres. Measurements and counts were taken following Delling (2002). The following abbreviations were used for morphometric and meristic characters: AFH, anal fin height; AFL, anal fin length; AP, anal fin pterygiophores; APL, anal peduncle length; AR, anal fin rays; BA, body depth, at level of origin of anal fin; BD, body depth, at level of origin of dorsal fin; BLD, body least depth; Bq, left side branquiostegals; $\mathrm{C}$, central caudal 


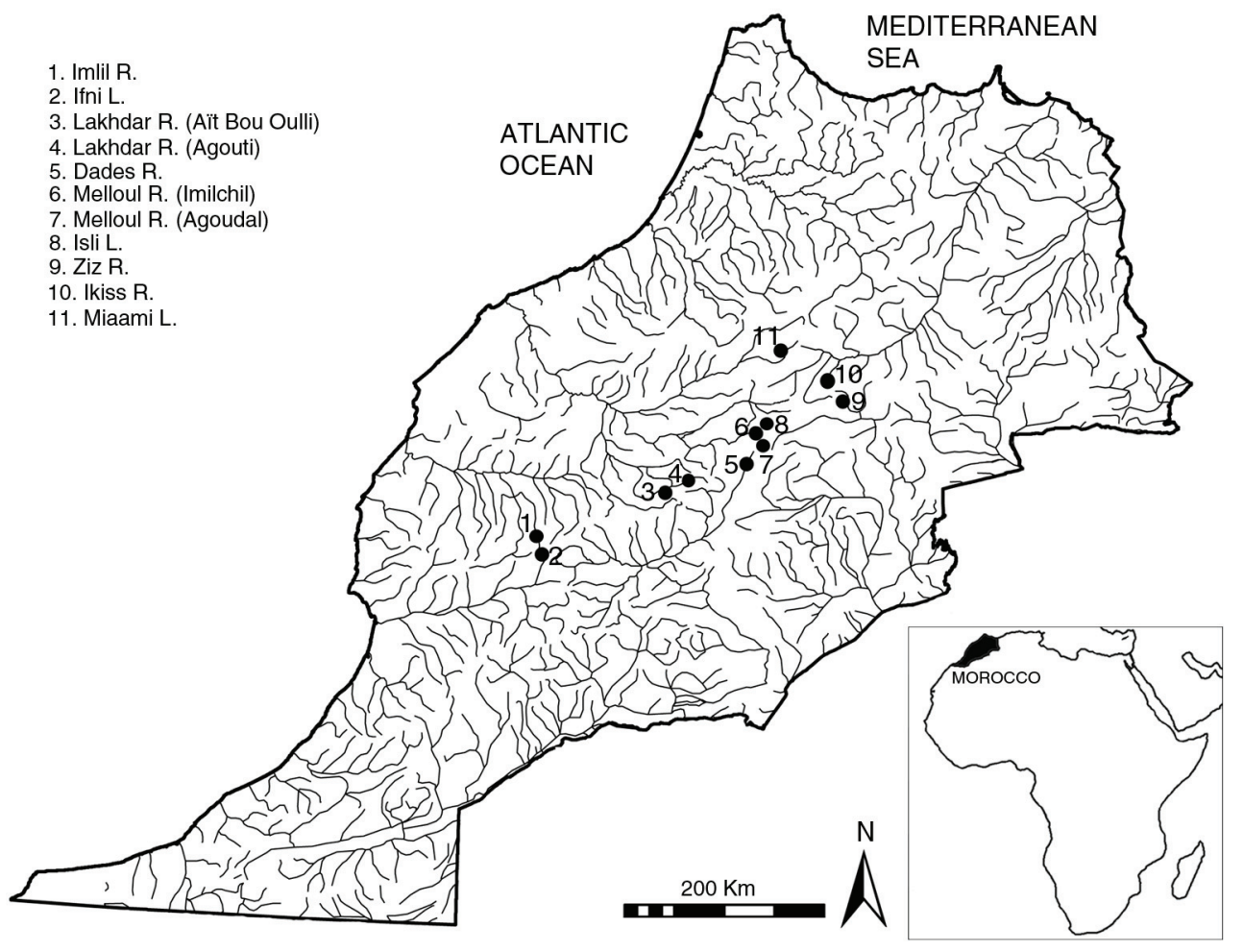

Fig. 1.- Sampling localities of Atlantic Salmo populations in Morocco.

Fig. 1.- Localidades de muestreo de las poblaciones atlánticas de Salmo en Marruecos.

fin rays; CFL, length of lower caudal fin lobe; CPA, caudal peduncle length at level of end of adipose fin; CPL, caudal peduncle length at level of end of dorsal fin; Cpr, number of procurrent rays upper caudal lobe. DFL, dorsal fin length; DFH, dorsal fin height; DP, dorsal fin pterygiophores; DR, dorsal fin rays; EDH, horizontal eye diameter; EDV, vertical eye diameter; HL, head length; LL, lateral line scales; ML, length of maxilla, from premaxilla end to posterior end of maxilla; PFL, pectoral fin length; PrAD, preanal distance; PrDD, predorsal distance; PrOL, preorbital length; PrPD, prepectoral distance, PrVD, preventral distance; PsOL, postorbital length, RSA, scales from base of adipose fin to lateral line; SL, standard length; UJD, upper jaw depth; UJL, upper jaw length, from symphysis of premaxilla to posterior end of maxilla; VFL, ventral fin length; Ve, total number of vertebrae. Number of vertebrae was obtained by direct counting on X-rays images of individuals from all studied populations.

After constructing the measurement matrix, Burnaby's method was used to correct size effect (Burnaby, 1966; Rohlf \& Bookstein, 1987). All analyses were conducted with the corrected matrix. Morphometric and meristic characters were analysed independently. A two-way analysis of variance (ANOVA) comparing morphometric characters was conducted to test for sexual dimorphism and variation among populations. To identify the variables that contributed most to the variation among populations, a principal components analysis (PCA) was performed using the covariance matrix for morphometric characters. Statistical analyses were carried out using PAST software (Hammer et al., 2001).

For the molecular approach, we analysed trout samples from Atlantic basins in Morocco corresponding to individuals of the genus Salmo from Ifni Lake (Salmo akairos), Isli Lake (Salmo sp.), Melloul R. (Salmo pellegrini), Miaami Lagoon (Salmo pellegrini), Dades R. (Salmo sp.), Lakhdar R. (Salmo pellegrini), Imlil R. (Salmo pellegrini) and Ziz R. (Salmo pellegrini) (Table 1). Likewise, we included one population from the Ikiss R. (Moulouya Basin) from the Mediterranean slope that has been associated to Atlantic trout populations (Tensift Basin) in previous molecular studies (Snoj et al., 2011). The species Salmo salar and Salmo orhidanus were selected as outgroups on the basis of previous phylogenetic analyses (Snoj et al., 2011). Analyses included mitochondrial cytochrome $b$ gene (MT-CYTB) and control region $(C R)$ for all data sets. Total genomic DNA was extracted from fin-clip tissue using the commercial kit Biosprint15 for tissue and blood (Qiagen). For each specimen, the complete region (1140bp) of $M T-C Y T B$ and a fragment (947bp including gaps) of $C R$ were amplified. Primers and protocols used for PCR followed Machordom \& Doadrio (2001) for MT-CYTB and Bernatchez (2001) for CR. After checking PCR products on $1 \%$ agarose gels, they were purified by ExoSAP-IT ${ }^{\mathrm{TM}}$ (USB) and directly sequenced on 
Table 1.- Sampling localities for Salmo spp from Moroccan Atlantic basins and GenBank Accession numbers.

Tabla 1.- Localidades de muestreo de las especies de Salmo spp de las cuencas atlánticas de Marruecos y números de acceso de GenBank.

\begin{tabular}{|c|c|c|c|}
\hline Population (Individuals) & Locality & GenBank Accession Numbers & Number in map \\
\hline Tensift (11) & Imlil River, Tensift Basin, Morocco & $\begin{array}{l}\text { MT-CYTB: KT279196-KT279198; } \\
\text { CR: KT279164-KT279166 }\end{array}$ & 1 \\
\hline Ifni (30) & Ifni Lake, Aït Igran, Morocco & $\begin{array}{l}\text { MT-CYTB: KT279176-KT279177; } \\
\text { CR: KT279144-KT279145 }\end{array}$ & 2 \\
\hline Lakhdar 1 (16) & $\begin{array}{l}\text { Lakhdar River, Oum er Rbia Basin } \\
\text { Aït Bou Oulli, Morocco }\end{array}$ & $\begin{array}{l}\text { MT-CYTB: KT279189-KT279191; } \\
\text { CR: KT279157-KT279159 }\end{array}$ & 3 \\
\hline Lakhdar 2 (10) & $\begin{array}{l}\text { Lakhdar River, Oum er Rbia Basin, } \\
\text { Agouti, Morocco }\end{array}$ & 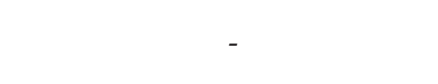 & 4 \\
\hline Dades (31) & $\begin{array}{l}\text { Dades River, Draa basin, Aitt Aatou } \\
\text { O'Moussa, Morocco }\end{array}$ & $\begin{array}{l}\text { MT-CYTB: KT279185-KT279188; } \\
\text { CR: KT279153-KT279156 }\end{array}$ & 5 \\
\hline Melloul 1 (13) & $\begin{array}{l}\text { Assif Melloul, Oum er Rbia Basin, } \\
\text { Agoudal, Morocco }\end{array}$ & $\begin{array}{l}\text { MT-CYTB: KT279172-KT279175; } \\
\text { CR: KT279140-KT279143 }\end{array}$ & 6 \\
\hline Melloul 2 (8) & $\begin{array}{l}\text { Assif Melloul, Oum er Rbia Basin. } \\
\text { Imilchil, Morocco }\end{array}$ & - & 7 \\
\hline Isli (20) & Isli Lake, Imilchil. Morocco & $\begin{array}{l}\text { MT-CYTB: KT279180-KT279184; } \\
\text { CR: KT279148-KT279152 }\end{array}$ & 8 \\
\hline Ziz (18) & $\begin{array}{l}\text { Ziz River, Ziz basin, Zaouia Sidi } \\
\text { Hamza, Morocco }\end{array}$ & $\begin{array}{l}\text { MT-CYTB: KT279184-KT279186; } \\
\text { CR: KT279164-KT279166 }\end{array}$ & 9 \\
\hline Moulouya (12) & $\begin{array}{l}\text { Ikiss River, Moulouya Basin, } \\
\text { Tattiouine, Morocco }\end{array}$ & $\begin{array}{l}\text { MT-CYTB: KT279192-KT279195; } \\
\text { CR: KT279160-KT279163 }\end{array}$ & 10 \\
\hline Miaami (14) & $\begin{array}{l}\text { Miaami Lagoon, Oum er Rbia Basin, } \\
\text { Douar Khamlich, Morocco }\end{array}$ & $\begin{array}{l}\text { MT-CYTB: KT279178-KT279179; } \\
\text { CR: KT279146-КT279147 }\end{array}$ & 11 \\
\hline
\end{tabular}

MACROGEN service using a 3730XLDNA sequencer. All generated new sequences were deposited in the GenBank database (Accession Numbers: MT-CYTB: KT279167-279198, CR: KT279135-KT279166).

Phylogenetic analyses were performed using Bayesian inference (BI) implemented in MrBayes v. 3.2 (Ronquist et al., 2012). The best-fitting models of sequence evolution for MT-CYTB and the $C R$ under the AIC criterion (Akaike, 1973) were selected using PartitionFinder v1.1.1. (Lanfear et al., 2012). The best model scheme for running phylogenetic analysis was constituted by four partitions: $C R(\mathrm{HKY}+\mathrm{I})$, $M T-C Y T B 1^{\text {st }}$ aminoacidic position (K80), MT-CYTB $2^{\text {nd }}$ aminoacidic position (F81) and $M T-C Y T B 3^{\text {rd }}$ aminoacidic position $(\operatorname{TrN})$. This partitioning scheme was used in phylogenetic performance unlinking evolutionary models among partitions. Bayesian analysis was performed using two independent runs of four Markov Montecarlo coupled chains (MCMC) of $10^{6}$ generations each, to estimate the posterior probability distribution. Topologies were sampled every 100 generations, and majority-rule consensus tree was estimated after discarding the first $10 \%$ of generations. Robustness of clades was assessed using Bayesian posterior probabilities. The average genetic distances between Salmo populations were calculated for each gene using MEGA package v.6.0 (Tamura et al., 2013) according to the uncorrected- $p$ distances.

\section{Results and Discussion \\ MORPHOLOGICAL COMPARISON BETWEEN POPULATIONS}

Analysis of variance (ANOVA) for sexual dimorphism showed significant differences between sexes $(p<0.05)$ for variables associated with preorbital length, anal fin and body depth (Table 2). Orbital size was also different in males in relation to females but probably as a consequence of the large difference in eye size in the Ifni lake population (in comparison to the other populations). When we removed the Ifni Lake population from the analysis no significant differences were found between males and females. In general, all variables showing significant dimorphism were greater in females than in males (Table 3). Due to the presence of sexual dimorphism and because we collected few female samples $(\mathrm{n}=38)$, we removed females for subsequent morphological analyses.

On the other hand, most of the morphometric variables showed significant differences between populations in the two-way ANOVA analysis (Table 2). An analysis of body proportions based on non-parametric Kruskal-Wallis and Mann-Whitney post hoc comparisons were used, to find differences in body shape between populations that can remain masked if only linear untransformed measurements are considered. 
Table 2.- Two-way analysis of variance (ANOVA) for sexual dimorphism, population variation, and their interaction. Significant differences $p<0.01\left(^{*}\right) . N=38$ females and $\mathrm{N}=119$ males. Abbreviations are described in the Material and Methods epigraph.

Tabla 2.- Análisis de la varianza (ANOVA) de dos vías para dimorfismo sexual, variación poblacional y su interacción. Diferencias significativas $p<0.01\left(^{*}\right) . N=38$ hembras y $\mathrm{N}=119$ machos. Las abreviaturas se describen en el epígrafe de Material y Métodos.

\begin{tabular}{|c|c|c|c|}
\hline Variables & $\begin{array}{c}\text { Sexual dimorphism } \\
\text { (f/p-value) }\end{array}$ & $\begin{array}{c}\text { Population Variation } \\
\text { ( } \mathrm{f} / \mathrm{p} \text {-value) }\end{array}$ & $\begin{array}{c}\text { Sex/pop Variation } \\
\text { (f/p-value) }\end{array}$ \\
\hline SL & $1.8 /$ & $87.95 /^{\star}$ & $5.8 /^{*}$ \\
\hline $\mathrm{HL}$ & $6.38 /$ & $6.43 /^{*}$ & $0.33 /$ \\
\hline PrOL & $25.88 /^{*}$ & $12.76 /^{\star}$ & $2.56 /$ \\
\hline EDH & $10.71 /^{*}$ & $26.91 /^{\star}$ & $2.21 /$ \\
\hline EDV & $38.23 /^{*}$ & $82.9 /^{*}$ & $0.88 /$ \\
\hline $\mathrm{PsOL}$ & $3.35 /$ & $9.81 /$ & $7.58 /^{\star}$ \\
\hline UJL & $1.65 /$ & $286.1 /^{*}$ & $3.43 /$ \\
\hline ML & $1.3 /$ & $17.82 /^{\star}$ & $0.71 /$ \\
\hline UJD & $2.44 /$ & $6.19 /^{\star}$ & $5.48 /^{*}$ \\
\hline PrDD & $0.02 /$ & $16.9 /^{*}$ & $3.62 /$ \\
\hline PrPD & $1.06 /$ & $6.3 /^{*}$ & $1.5 /$ \\
\hline PrVD & $0.96 /$ & $22.94 /^{\star}$ & $2.43 /$ \\
\hline PrAD & $5.89 /$ & $47.82 /^{*}$ & $4.24 /^{\star}$ \\
\hline CPL & $0.003 /$ & $67.6 /^{*}$ & $1.96 /$ \\
\hline CPA & $1.29 /$ & $5.93 /{ }^{*}$ & $1.53 /$ \\
\hline APL & $24.46 /$ & $0.02 /^{*}$ & $0.38 /$ \\
\hline PFL & $1.1 /$ & $10.3 /^{*}$ & $1.98 /$ \\
\hline DFL & $0.7 /$ & $35.8 /^{*}$ & $0.55 /$ \\
\hline DFH & $0.005 /$ & $32.6 /^{*}$ & $9.91 /^{*}$ \\
\hline VFL & $5.93 /$ & $7.91 /{ }^{*}$ & $0.64 /$ \\
\hline AFL & $8.36 /{ }^{*}$ & $1.6 /$ & $0.16 /$ \\
\hline AFH & $27.56 /^{*}$ & $38.25 /^{\star}$ & $2.2 /$ \\
\hline CFL & $0.83 /$ & $10.84 /^{*}$ & $1.22 /$ \\
\hline BLD & $24.38 /^{*}$ & $33.48 /^{*}$ & $1.78 /$ \\
\hline BA & $6.57 /$ & $5.64 /^{*}$ & $0.69 /$ \\
\hline BD & $17.18 /^{*}$ & $33.17 /^{\star}$ & $2.51 /$ \\
\hline
\end{tabular}

Table 3.- Morphometric variables showing significant sexual dimorphism $(p<0.01)$. Values are means and between brackets maximum y minimum values. Abbreviations are described in the Material and Methods epigraph.

Tabla 3.- Variables morfométricas que muestran dimorfismo sexual significativo $(p<0.01)$. Los valores representan medias y entre paréntesis valores máximos y mínimos. Las abreviaturas están descritas en el epígrafe de Material y Métodos.

\begin{tabular}{lll}
\hline Variables $(\mathbf{m m})$ & \multicolumn{1}{c}{ Males $(\mathbf{n = 1 1 9})$} & \multicolumn{1}{c}{ Females $(\mathbf{n = 3 8})$} \\
\hline PrOL & $7.7(35.4-3.3)$ & $8.04(19.9-4.3)$ \\
EDH & $7.9(16.5-4.7)$ & $9.52(13.1-5.9)$ \\
EDV & $6.9(14.3-3.9)$ & $8.51(12.5-6)$ \\
AFL & $13.6(47.1-7)$ & $16.12(33.1-8)$ \\
AFH & $22(59.9-12.4)$ & $25.99(45.3-13.8)$ \\
BLD & $14.2(40.2-8.1)$ & $16.52(29.7-9.1)$ \\
BD & $33.6(100.9-17.5)$ & $39.44(80.6-20.6)$ \\
\hline
\end{tabular}

According to these analyses, morphological differences in body shape were found in almost all morphometric measurements (Appendix 1). The population from Isli Lake showed the largest body size compared to the remaining populations. Otherwise, the maxilla in the Isli population was long but not significantly larger than in the other populations (Table 4). In Isli Lake trout, the size of the eye was smallest of all populations studied, but since mature individuals from this population exhibited the largest body size of all studied populations, the smaller size eye found in this population could reflect allometric growth (Table 4). The Isli Lake individuals showed the smallest pectoral fin in comparison to other populations. The population of Miaami Lagoon in the upstream Chbouka River also had a long preorbital distance, which is in agreement with a well-developed maxilla in length and height. Trout of Miaami Lagoon were shorter, which is revealed in body depth and caudal 
Table 4.- Values of the means and between brackets maximum and minimum, to different ratios of the morphometric variables and scales count. Abbreviations are described in the Material and Methods epigraph.

Tabla 4.- Valores de la media, y entre paréntesis valores máximos y mínimos, para diferentes proporciones de las variables morfométricas y número escamas. Las abreviaturas están descritas en el epígrafe de Material y Métodos.

\begin{tabular}{lccccccccc}
\hline Measurements & $\begin{array}{c}\text { Ziz } \\
\mathbf{n = 8}\end{array}$ & $\begin{array}{c}\text { Dades } \\
\mathbf{n = 2 3}\end{array}$ & $\begin{array}{c}\text { Lahkdar } \\
\mathbf{n = 2 2}\end{array}$ & $\begin{array}{c}\text { Melloul } \\
\mathbf{n = 2 0}\end{array}$ & $\begin{array}{c}\text { Miaami } \\
\mathbf{n = 1 4}\end{array}$ & $\begin{array}{c}\text { Isli } \\
\mathbf{n = 1 5}\end{array}$ & $\begin{array}{c}\text { Ifni } \\
\mathbf{n = 1 7}\end{array}$ & $\begin{array}{c}\text { Moulouya } \\
\mathbf{n = 1 2}\end{array}$ & $\begin{array}{c}\text { Tensift } \\
\mathbf{n = 1 1}\end{array}$ \\
\hline HL/PrOL & $5.2(5.7-4.7)$ & $5.1(5.5-4.7)$ & $4.7(5.3-4.3)$ & $4.6(6.3-3.9)$ & $3.4(3.6-3.1)$ & $3.7(4.5-2.9)$ & $4.8(5.3-4.4)$ & $5.1(5.6-4.6)$ & $5.3(5.6-5)$ \\
HL/ML & $2.1(2.2-2)$ & $2(2.2-1.9)$ & $2.1(2.3-2)$ & $2.1(2.3-1.9)$ & $2(2.1-1.9)$ & $2(2.2-1.7)$ & $1.9(2.2-1.7)$ & $2.1(2.2-2)$ & $2.1(2.2-2)$ \\
HL/UJL & $3.2(3.4-2.9)$ & $3.2(3.5-2.9)$ & $2.9(3.1-2.6)$ & $2.8(3.1-2.5)$ & $2.4(2.5-2.2)$ & $2.4(2.6-2.2)$ & $2.2(2.5-2)$ & $2.8(3-2.6)$ & $2.8(2.9-2.6)$ \\
ML/UJD & $3.9(4.5-3.7)$ & $4.5(4.9-4)$ & $3.8(4.3-3.1)$ & $4(4.7-3.3)$ & $3.6(3.9-3)$ & $4.3(5.3-3.5)$ & $4.9(5.6-4.1)$ & $4.6(5.4-3.6)$ & $5.1(5.7-4.7)$ \\
SL/PFL & $4.5(5.3-3.9)$ & $4.8(5-4.6)$ & $4.9(5.4-4.2)$ & $4.9(5.6-4.1$ & $4.2(4.6-3.8)$ & $5.7(6-5.2)$ & $4.6(5-4.6)$ & $5(5.6-4.4)$ & $5(5.2-4.7)$ \\
HL/EDV & $4(4.5-3.8)$ & $3.8(4.1-3.3)$ & $4.3(5.1-3.8)$ & $4.8(5.6-3.8)$ & $5.3(6-4.4)$ & $6(7.2-5)$ & $4.7(5-4.5)$ & $4.5(5-3.9)$ & $4.6(4.9-4.3)$ \\
HL/EDH & $3.4(4-3.1)$ & $3.2(3.5-3)$ & $3.8(4.2-3.3)$ & $4.1(4.6-3.5)$ & $4.9(6.3-3.4)$ & $5.4(6.4-4.4)$ & $3.5(4.7-3.1)$ & $3.8(4-3.5)$ & $3.6(3.8-3.4)$ \\
SL/CPL & $2.4(2.5-2.3)$ & $2.4(2.6-2.3)$ & $2.3(2.6-2.1)$ & $2.2(2.3-2.1)$ & $2.2(2.3-2.1)$ & $2.2(2.4-2)$ & $2.5(2.6-2.4)$ & $2.2(2.3-2.1)$ & $1.6(1.7-1.5)$ \\
SL/APL & $4.9(5.1-4.7)$ & $5(5.4-4.7)$ & $4.8(5.2-4.5)$ & $5.1(5.8-4.6)$ & $4.9(5.2-4.6)$ & $5.4(5.9-4.9)$ & $5.7(6.3-5.3)$ & $4.6(4.9-4.3)$ & $4.7(5-4.5)$ \\
APL/BLD & $1.8(1.9-1.7)$ & $1.9(2.1-1.7)$ & $2(2.2-1.8)$ & $1.8(2-1.6)$ & $1.8(1.9-1.7)$ & $1.9(2.1-1.8)$ & $1.5(1.6-1.4)$ & $2(2-1.8)$ & $1.9(1.7-1.4)$ \\
CPL/BLA & $1(1-0.9)$ & $1(1.1-0.9)$ & $1(1.1-0.9)$ & $1.1(1.4-1)$ & $1.1(1.3-1)$ & $1.2(1.3-1.1)$ & $1.1(1.2-1)$ & $2.4(2.7-2.1)$ & $1.6(1.7-1.5)$ \\
SL/BLD & $8.9(9.3-8.5)$ & $9.4(9.8-9)$ & $9.6(10.4-8.9)$ & $9(10-8.4)$ & $8.7(8.8-8.2)$ & $10.4(11.1-9.6)$ & $8.6(9.1-8.3)$ & $9.2(9.8-8.6)$ & $9(9.3-8.4)$ \\
SL/BD & $4(4.1-3.7)$ & $4.2(4.5-3.9)$ & $4.1(4.3-3.7)$ & $3.9(4.4-3.6)$ & $3.7(4.3-3.4)$ & $4(4.3-3.7)$ & $4.1(4.3-3.8)$ & $3.6(4.1-3.3)$ & $3.7(3.8-3.6)$ \\
\hline
\end{tabular}

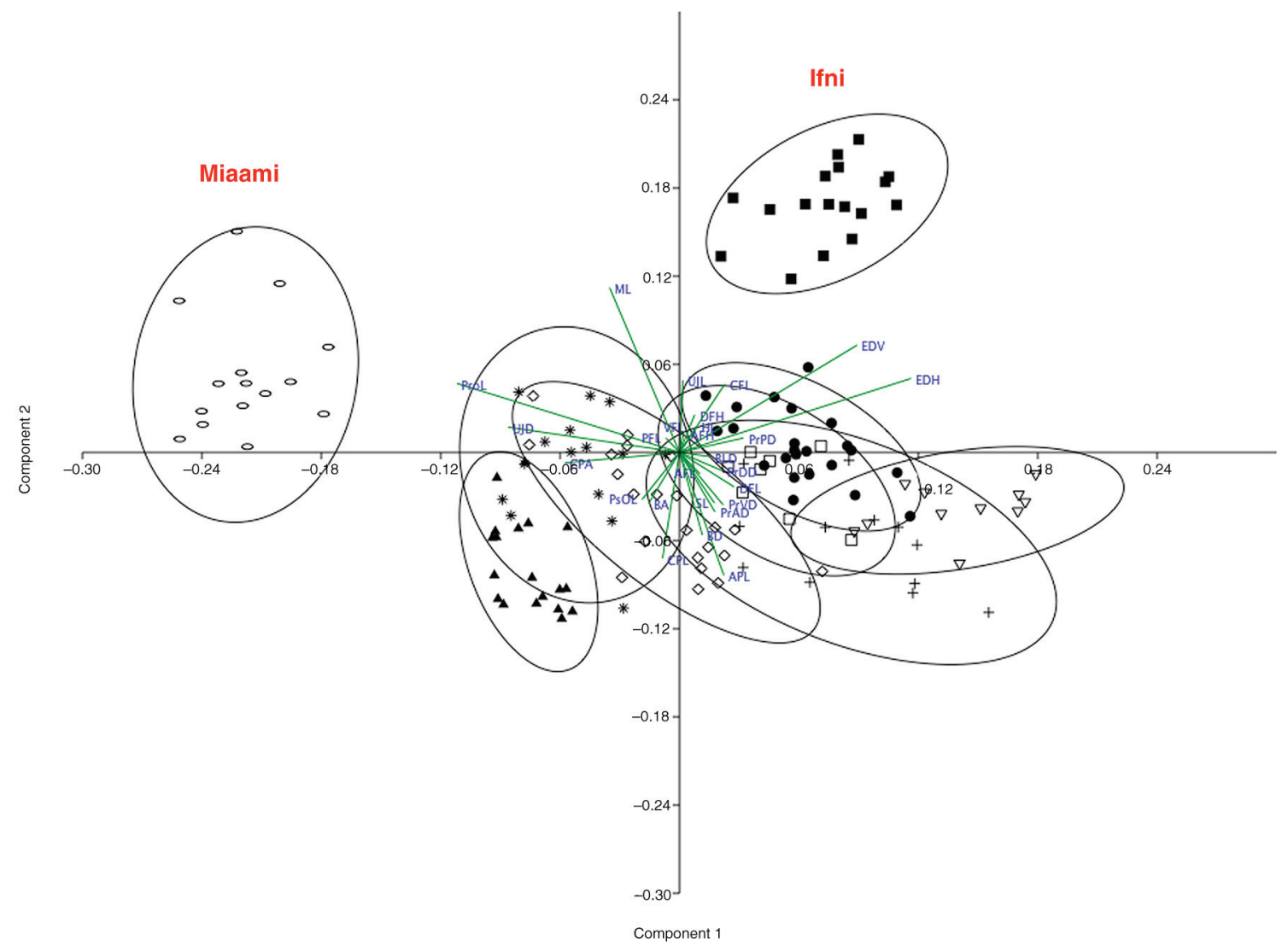

Fig. 2.- Variables that most contributed to the PCA analysis. Square, Ziz population. Dot, Dades population. Filled Triangle, Melloul population. Diamond, Lakhdar population. Oval, Miaami population. Star, Isli population. Filled Square, Ifni population. Plus, Moulouya population. Inverted triangle, Tensift population. Abbreviations are described in the Material and Methods epigraph.

Fig. 2.- Variables que más contribuyen al ordenamiento en el PCA. Cuadrado vacío, población del Ziz. Puntos negros, población del Dades. Triángulo relleno, población del Melloul. Rombos, población del Lakhdar. Óvalos, población de Miaami. Estrellas, población de Isli. Cuadrados negros, población de Ifni. Signo de mas, población del Moulouya. Triángulo invertido. Población del Tensift. Las abreviaturas están descritas en el epígrafe de Material y Métodos. 
peduncle measurements. The Ifni Lake population, a trout population having small-sized mature individuals, presented the largest eye size in adult specimens (Table 4). The maxilla was very long and narrow and the caudal peduncle was shorter and deeper in the Ifni population than in other populations (Table 4). Dades, Moulouya, Ziz and Tensift populations were characterized by having shorter preorbital length and Dades and Ziz populations by shorter maxillary length. The height of maxilla was largest in the Dades population. Moulouya and Tensift populations showed long caudal peduncle in relation to the body height considered from the origin of the anal fin. The upper mandibular length was largest in the Moulouya and Tensift populations with respect to head length. The Tensift population had a smaller dorsal fin relative to the remaining populations.

The PCA divided the Salmo populations into three groups that correspond to those of Ifni Lake, those of Miaami Lagoon and a third large group containing the remaining Salmo populations (Fig. 2). The eigenvalues for the two first Principal Components, with the Burnaby-corrected matrix for removing size effect, mostly explained the variance (Table 5). The variables that contributed most to the ordination in the PCA were orbital and preorbital lengths, caudal peduncle lengths, size and height of the maxilla and length of the dorsal fin (Table 5).

With regard to meristic characters, we found no significant differences according to Kruskal-Wallis and Mann-Whitney non parametric analyses for the following traits: number of vertebrae, number of scales in lateral line, number of scales in transversal on adipose fin, number of rays in dorsal and anal fins, number of procurrent rays on the caudal fin and number of branchyostegal rays. Only two traits showed significant differences, dorsal and anal pterygophores (Table 6). The number of pterygophores in dorsal fin had its highest value in Salmo akairos and its lowest value in the Isli Lake population (Fig. 3). Likewise, the number of pterygophores in the anal fin presented its highest value in Salmo pallaryi from Sidi Ali Lake comparing with the remaining populations studied (Fig. 3). The species Salmo akairos (Ifni population) also showed significant differences in relation to the other populations in anal fin pterygophores.

\section{MOLECULAR APPROACHES}

The concatenated matrix including both mitochondrial genes rendered a total of 2088bp (MT-CYTB: 1140bp $+C R$ : $947 \mathrm{bp}$ including gaps). Bayesian tree reconstruction revealed well-supported phylogenetic relationships among trout populations from Morocco and demonstrated the early divergence of the Dades population (Draa basin) from the others (Fig. 4). In fact, the genetic distances between Dades and the remaining
Table 5.- Eigenvalues and eigenvectors for the first three principal components (PC1-PC3) from 26 morphometric variables for Salmo populations. Abbreviations are described in the Material and Methods epigraph. In bold, variables with the highest eigenvectors for each PC.

Tabla 5.- Eigenvalores y eigenvectores para los tres primeros componentes principales (CP1-CP3) de 26 variables morfométricas para las poblaciones del género Salmo. Las abreviaturas están descritas en el epígrafe de Material y Métodos. En negrita, variables con los eigenvectores más altos para cada CP.

\begin{tabular}{|c|c|c|c|}
\hline & PCI & PCII & PCIII \\
\hline Eigenvalue & 0.0104 & 0.0062 & 0.0023 \\
\hline$\%$ variance & 36.9 & 21.9 & 8.1 \\
\hline \multicolumn{4}{|c|}{ Eigenvectors } \\
\hline SL & 0.0771 & -0.1514 & -0.0995 \\
\hline PrOL & -0.4919 & -0.2065 & 0.0099 \\
\hline EDH & 0.5113 & -0.2211 & 0.1297 \\
\hline EDV & 0.3921 & -0.3209 & 0.0051 \\
\hline PsOL & -0.0826 & -0.1408 & -0.0858 \\
\hline HL & 0.0383 & 0.07642 & -0.0367 \\
\hline ML & -0.1543 & -0.4928 & -0.3069 \\
\hline UJL & 0.0073 & -0.2163 & 0.0366 \\
\hline UJD & -0.3787 & -0.0756 & 0.5507 \\
\hline PrDD & 0.0954 & -0.0553 & -0.2162 \\
\hline PrPD & 0.1411 & 0.0431 & -0.0750 \\
\hline PrVD & 0.0965 & -0.1573 & -0.1716 \\
\hline PrAD & 0.0781 & -0.1777 & -0.1449 \\
\hline CPL & -0.0375 & 0.317 & -0.1039 \\
\hline CPA & -0.2534 & -0.0311 & -0.3269 \\
\hline APL & -0.0979 & 0.3675 & 0.2367 \\
\hline PFL & -0.0298 & -0.0432 & 0.1755 \\
\hline DFL & -0.1207 & 0.1032 & 0.3579 \\
\hline DFH & 0.3336 & -0.1125 & 0.1111 \\
\hline VFL & 0.0087 & -0.0663 & 0.2682 \\
\hline AFL & 0.0450 & 0.0558 & 0.2872 \\
\hline AFH & 0.0343 & -0.0697 & 0.1134 \\
\hline CFL & 0.0999 & -0.2044 & -0.0057 \\
\hline BLD & 0.0679 & -0.0124 & -0.0947 \\
\hline BA & -0.0679 & -0.1518 & 0.1115 \\
\hline BD & -0.0504 & 0.2473 & -0.0186 \\
\hline
\end{tabular}

populations, including the recognized species Salmo akairos (Ifni), were the highest recorded for both genes and for all comparisons (Table 7). The Dades populations also showed nine autapomorphies in the MT-CYTB, all of them transitions (Table 9). Genetic distances among the rest of trout populations from Morocco ranged from $0.2-0.6 \%$ for $M T-C Y T B$ and $0.2-0.5 \%$ for $C R$ (Table 7). Autapomorphies in the MT-CYTB gene, although not so numerous as in the Dades population, were found in the Ifni, Isli, Lakhdar and Tensift populations (Table 8). 
Table 6.- Non-parametric Kruskal-Wallis test and Mann-Whitney's post hoc comparisons for testing significant differences in pterygophores in dorsal fin (above diagonal) and anal fin (below diagonal) among Atlantic Moroccan trout populations. Significant values are presented in bold.

Tabla 6.- Test no paramétrico de Kruskal-Wallis y comparaciones post hoc de Mann-Whitney para testar diferencias significativas en los pterigóforos de la aleta dorsal (sobre la diagonal) y de la aleta anal (debajo de la diagonal) entre las poblaciones atlánticas de truchas de Marruecos. Valores significativos se representan en negrita.

\begin{tabular}{lccccccccc}
\hline Population & $\begin{array}{c}\text { Ziz } \\
\mathbf{N = 2 0}\end{array}$ & $\begin{array}{c}\text { Lakhdar } \\
\mathbf{N = 1 0}\end{array}$ & $\begin{array}{c}\text { Isli } \\
\mathbf{N = 1 0}\end{array}$ & $\begin{array}{c}\text { Dades } \\
\mathbf{N = 1 5}\end{array}$ & $\begin{array}{c}\text { Miaami } \\
\mathbf{N = 1 0}\end{array}$ & $\begin{array}{c}\text { Sidi Ali } \\
\mathbf{N = 1 9}\end{array}$ & $\begin{array}{c}\text { Ifni } \\
\mathbf{N = 2 0}\end{array}$ & $\begin{array}{c}\text { Tensift } \\
\mathbf{N = 1 1}\end{array}$ & $\begin{array}{c}\text { Moulouya } \\
\mathbf{N = 1 2}\end{array}$ \\
\hline Ziz & - & 0.765 & $\mathbf{0 . 0 0 3}$ & 0.354 & 0.464 & $\mathbf{0 . 0 0 7}$ & $\mathbf{0 . 0 0 0 0 2}$ & 0.085 & 0.267 \\
Lakhdar & 0.582 & - & $\mathbf{0 . 0 2 2}$ & 0.343 & 0.833 & 0.098 & $\mathbf{0 . 0 0 0 8}$ & 0.137 & 0.219 \\
Isli & 0.902 & 0.568 & - & $\mathbf{0 . 0 0 0 8}$ & $\mathbf{0 . 0 1 8}$ & 0.140 & $\mathbf{0 . 0 0 0 3}$ & $\mathbf{0 . 0 0 0 6}$ & $\mathbf{0 . 0 0 0 9}$ \\
Dades & 0.974 & 0.617 & 0.955 & - & 0.120 & $\mathbf{0 . 0 0 0 5}$ & $\mathbf{0 . 0 0 0 0 4}$ & 0.365 & 0.812 \\
Miaami & 0.683 & 0.398 & 0.849 & 0.767 & - & 0.089 & $\mathbf{0 . 0 0 0 1}$ & $\mathbf{0 . 0 2 9}$ & 0.097 \\
Sidi Ali & $\mathbf{0 . 0 0 0 1}$ & $\mathbf{0 . 0 0 0 1}$ & $\mathbf{0 . 0 0 0 2}$ & $\mathbf{0 . 0 0 0 5}$ & $\mathbf{0 . 0 0 0 7}$ & - & $\mathbf{0 . 0 0 0 0 1}$ & $\mathbf{0 . 0 0 0 1}$ & $\mathbf{0 . 0 0 0 6}$ \\
Ifni & $\mathbf{0 . 0 1 9}$ & 0.096 & $\mathbf{0 . 0 4 1}$ & $\mathbf{0 . 0 3 1}$ & $\mathbf{0 . 0 2 0}$ & $\mathbf{0 . 0 0 0 1}$ & - & $\mathbf{0 . 0 0 0 3}$ & $\mathbf{0 . 0 0 0 1}$ \\
Tensift & 0.702 & 0.396 & 0.875 & 0.787 & 0.978 & $\mathbf{0 . 0 0 0 1}$ & $\mathbf{0 . 0 1 5}$ & - & 0.542 \\
Moulouya & 0.218 & 0.134 & 0.387 & 0.323 & 0.483 & $\mathbf{0 . 0 0 0 1}$ & $\mathbf{0 . 0 0 5}$ & 0.419 & - \\
\hline
\end{tabular}

\section{PIGMENTATION PATTERNS}

The Isli population showed a pigmentation pattern without spots and parr marks, as also occurred in Salmo pallaryi. The Dades population showed numerous irregular parr marks, usually greater to or equal than 14, which usually are retained in adult specimens. In the Dades population, the body is covered by small and numerous red and black spots that sometimes extend to the caudal fin and opercular area. Adult specimens from the Moulouya, Ziz and Oum er Rbia basins usually retained large and scarce parr marks. Adults from the Tensift population did not retain parr marks and showed a dark coloration (Fig. 5).

\section{OSTEOLOGICAL REMARKS}

Vomer teeth in Moroccan trout were arranged in zigzag with the exception of the Isli population, whose teeth were placed in one row within a narrow vomer. The vomer length was lesser than half of the parasphenoid length in all the studied populations except for the Ifni population. In this last population vomer length was greater than half of the parasphenoid length (Appendix 2).

For Dades individuals, the lateral processes of the ethmoid bone were extended, conferring a $\mathrm{T}$ shape to the bone, and the upper process of the premaxilla bone was small and laterally inclined. In comparison to other populations studied, where the upper maxillary
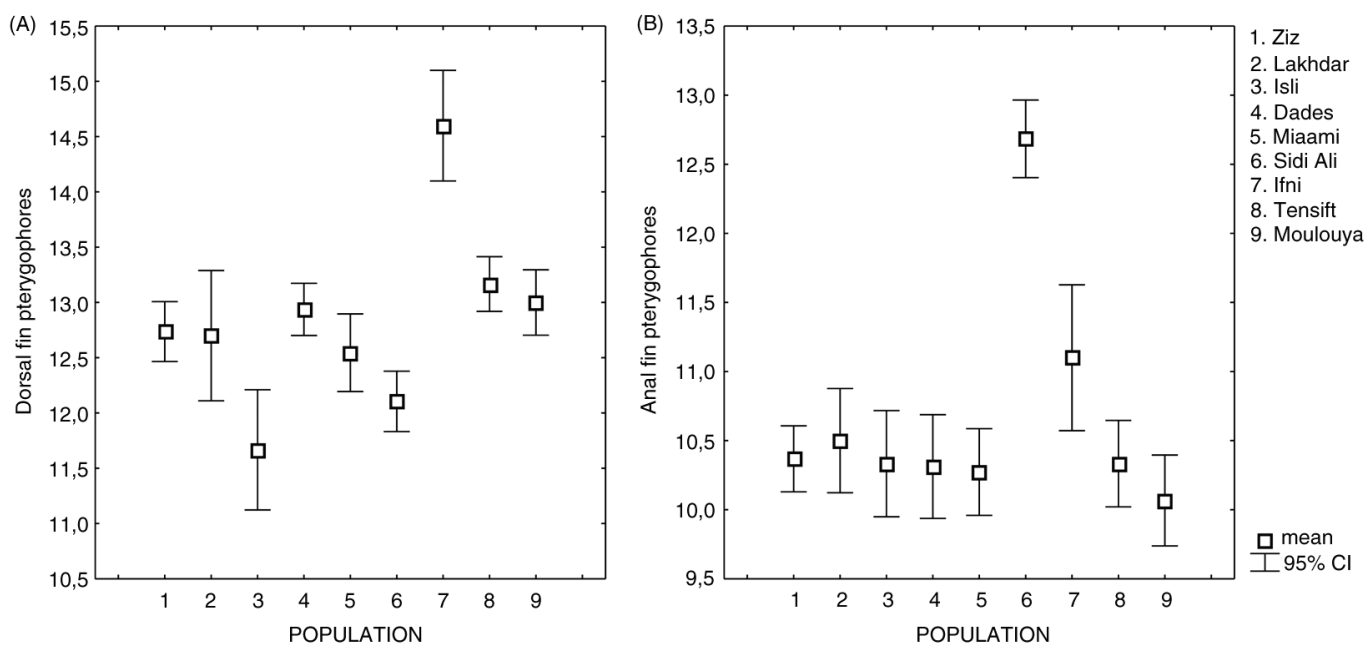

Fig. 3.- Boxplot of dorsal fin (A) and anal fin (B) pterygophores.

Fig. 3.- Boxplot de los pterigóforos de las aletas dorsal (A) y anal (B). 


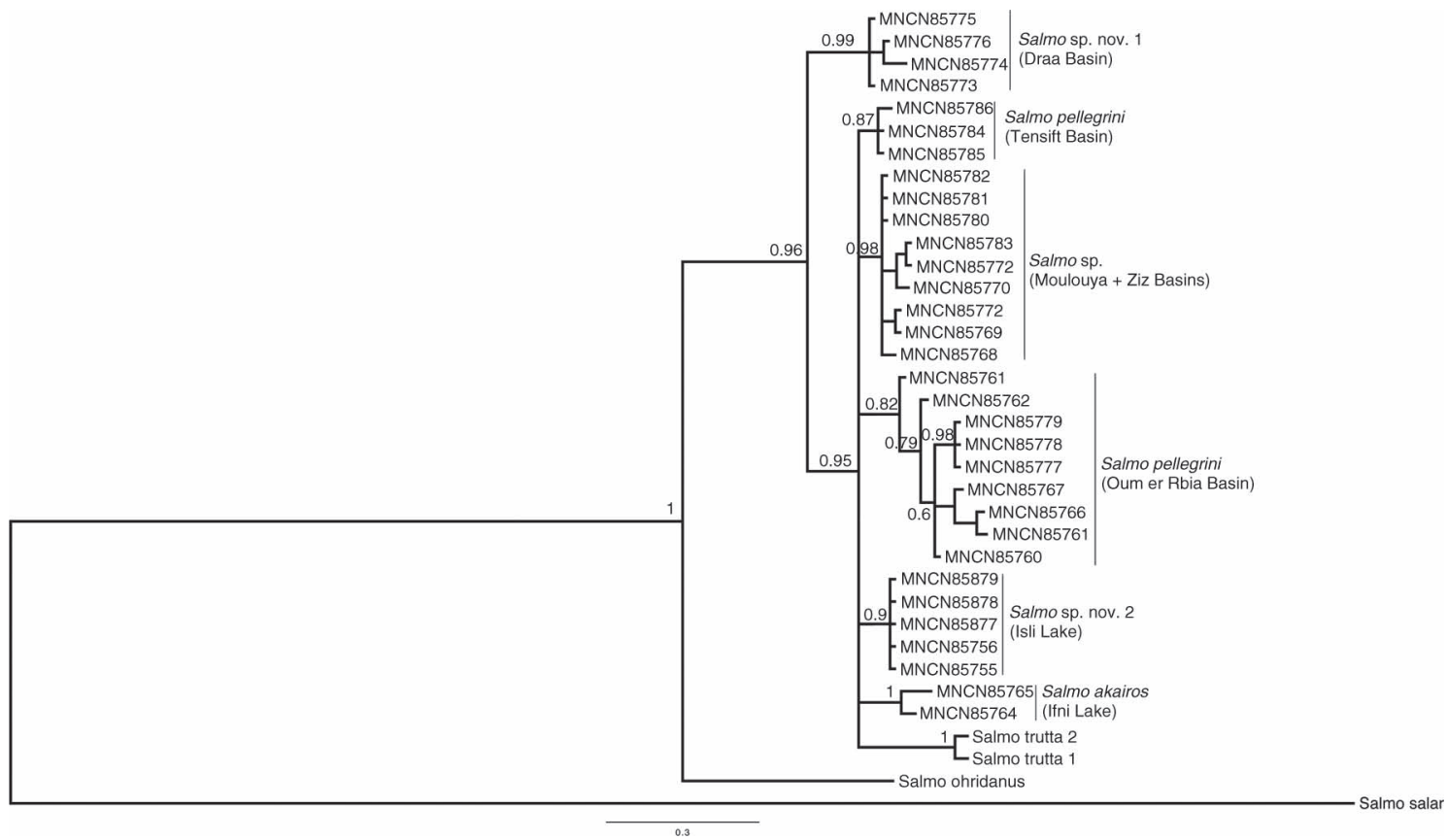

Fig. 4.- Phylogenetic tree rendered by Bayesian inference based on the concatenated matrix of both mitochondrial genes $(M T-C Y T B+C R)$. Numbers on branches indicate posterior probability values.

Fig. 4.- Árbol filogenético obtenido mediante inferencia Bayesiana a partir de la matriz concatenada de los dos genes mitocondriales $(M T-C Y T B+C R)$. Los números sobre las ramas indican valores de probabilidad posterior.

process was greater than $47 \%$, we found that the height of the upper maxillary process in the Ifni population was less than $45 \%$, with respect to the length of the basal plate. Most individuals of the Isli population had the premaxilla strongly ossified and extended over the maxilla (Appendix 2).

The upper jaw in the Dades, Ziz and Oum er Rbia basins was shorter than in the other populations. In the Ifni and Isli populations upper jaw length usually exceeded the posterior border of the eye. The Ifni population had the lowest maxilla, while the Miaami and Moulouya populations had the deepest. The skull was narrower in the Isli population and the snout was more pointed in Isli and Ifni lakes, in comparison to the other populations (Appendix 2).

The anterior maxillary process in the Isli population was thinner than in the remaining Moroccan populations and the inflection of this process, in relation to the

Table 7.- Uncorrected-p genetic distances, in percentage, among Atlantic Moroccan trout populations based on MT-CYTB gene (below diagonal) and the $C R$ (above diagonal). In bold on diagonal uncorrected- $p$ genetic distances within populations on the left MT-CYTB and on the right $C R$.

Tabla 7.- Distancias genéticas no corregidas, en porcentaje, entre las poblaciones atlánticas de trucha de Marruecos basadas en el gen MT-CYTB (debajo de la diagonal) y la CR (encima de la diagonal). En negrita en la diagonal distancias dentro de poblaciones, a la izquierda valores para el gen MT-CYTB y a la derecha valores de la CR.

\begin{tabular}{lllllllllll}
\hline Populations & $\mathbf{I f n i}$ & Isli & Melloul & Miaami & Dades & Lakhdar & Ziz & Moulouya & Tensift & S. trutta (Austria) \\
\hline Ifni & $\mathbf{0 . 1 / 0 . 1}$ & 0.21 & 0.34 & 0.32 & 0.53 & 0.32 & 0.30 & 0.21 & 0.32 & 0.48 \\
Isli & 0.53 & $\mathbf{0 . 1 / 0 . 0}$ & 0.32 & 0.32 & 0.42 & 0.32 & 0.08 & 0.00 & 0.11 & 0.37 \\
Melloul & 0.55 & 0.20 & $\mathbf{0 . 1 / 0 . 0}$ & 0.29 & 0.42 & 0.21 & 0.40 & 0.32 & 0.42 & 0.53 \\
Miaami & 0.61 & 0.26 & 0.07 & $\mathbf{0 . 1 / 0 . 0}$ & 0.21 & 0.32 & 0.40 & 0.32 & 0.42 & 0.48 \\
Dades & 1.14 & 0.96 & 0.99 & 1.05 & $\mathbf{0 . 1 / 0 . 0}$ & 0.53 & 0.51 & 0.42 & 0.53 & 0.58 \\
Lakhdar & 0.61 & 0.26 & 0.11 & 0.18 & 1.05 & $\mathbf{0 . 0 / 0 . 0}$ & 0.40 & 0.32 & 0.42 & 0.69 \\
Ziz & 0.56 & 0.39 & 0.41 & 0.47 & 1.00 & 0.47 & $\mathbf{0 . 1 / 0 . 1}$ & 0.08 & 0.06 & 0.33 \\
Moulouya & 0.55 & 0.37 & 0.39 & 0.46 & 0.99 & 0.46 & 0.40 & $\mathbf{0 . 4 / 0 . 0}$ & 0.11 & 0.37 \\
Tensift & 0.47 & 0.29 & 0.31 & 0.38 & 0.91 & 0.38 & 0.33 & 0.31 & $\mathbf{0 . 6 / 0 . 0}$ & 0.27 \\
S. trutta (Austria) & 1.11 & 0.92 & 0.94 & 1.00 & 1.36 & 1.01 & 0.96 & 0.94 & 0.86 & $\mathbf{0 . 1 / 0 . 1}$ \\
\hline
\end{tabular}


Table 8.- Autapomorphies in the MT-CYTB gene in Atlantic Moroccan populations of trout.

Tabla 8.- Autopomorfías en el gen MT-CYTB en las poblaciones de truchas atlánticas de Marruecos.

\begin{tabular}{lcccccccccccccc}
\hline $\begin{array}{l}\text { Population IMT-CYTB } \\
\text { Position }\end{array}$ & $\mathbf{6 0}$ & $\mathbf{1 4 4}$ & $\mathbf{2 1 6}$ & $\mathbf{2 3 4}$ & $\mathbf{4 4 7}$ & $\mathbf{4 7 4}$ & $\mathbf{5 0 4}$ & $\mathbf{5 0 8}$ & $\mathbf{6 1 6}$ & $\mathbf{7 3 2}$ & $\mathbf{8 4 9}$ & $\mathbf{9 1 5}$ & $\mathbf{9 9 0}$ & $\mathbf{1 0 9 0}$ \\
\hline Ifni & $\mathrm{T}$ & $\mathrm{A}$ & $\mathrm{T}$ & $\mathrm{C}$ & $\mathrm{C}$ & $\mathrm{T}$ & $\mathrm{C}$ & $\mathrm{G}$ & $\mathbf{T}$ & $\mathrm{G}$ & $\mathrm{C}$ & $\mathrm{T}$ & $\mathrm{A}$ & $\mathrm{G}$ \\
Isli & $\mathrm{T}$ & $\mathrm{A}$ & $\mathrm{T}$ & $\mathrm{C}$ & $\mathrm{T}$ & $\mathrm{T}$ & $\mathrm{C}$ & $\mathbf{A}$ & $\mathrm{A}$ & $\mathrm{G}$ & $\mathrm{C}$ & $\mathrm{T}$ & $\mathrm{A}$ & $\mathrm{G}$ \\
Melloul & $\mathrm{T}$ & $\mathrm{A}$ & $\mathrm{T}$ & $\mathrm{C}$ & $\mathrm{T}$ & $\mathrm{T}$ & $\mathrm{C}$ & $\mathrm{G}$ & $\mathrm{A}$ & $\mathrm{G}$ & $\mathrm{C}$ & $\mathrm{T}$ & $\mathrm{A}$ & $\mathrm{G}$ \\
Miaami & $\mathrm{T}$ & $\mathrm{A}$ & $\mathrm{T}$ & $\mathrm{C}$ & $\mathrm{T}$ & $\mathrm{T}$ & $\mathrm{C}$ & $\mathrm{G}$ & $\mathrm{A}$ & $\mathrm{G}$ & $\mathrm{C}$ & $\mathrm{T}$ & $\mathrm{A}$ & $\mathrm{G}$ \\
Dades & $\mathrm{C}$ & $\mathrm{A}$ & $\mathrm{C}$ & $\mathrm{C}$ & $\mathrm{T}$ & $\mathrm{C}$ & $\mathrm{T}$ & $\mathrm{G}$ & $\mathrm{A}$ & $\mathrm{A}$ & $\mathrm{T}$ & $\mathrm{C}$ & $\mathrm{G}$ & $\mathrm{A}$ \\
Lakhdar & $\mathrm{T}$ & $\mathrm{A}$ & $\mathrm{T}$ & $\mathrm{T}$ & $\mathrm{T}$ & $\mathrm{T}$ & $\mathrm{C}$ & $\mathrm{G}$ & $\mathrm{A}$ & $\mathrm{G}$ & $\mathrm{C}$ & $\mathrm{T}$ & $\mathrm{A}$ & $\mathrm{G}$ \\
Ziz & $\mathrm{T}$ & $\mathrm{A}$ & $\mathrm{T}$ & $\mathrm{C}$ & $\mathrm{T}$ & $\mathrm{T}$ & $\mathrm{C}$ & $\mathrm{G}$ & $\mathrm{A}$ & $\mathrm{G}$ & $\mathrm{C}$ & $\mathrm{T}$ & $\mathrm{A}$ & $\mathrm{G}$ \\
Moulouya & $\mathrm{T}$ & $\mathrm{A}$ & $\mathrm{T}$ & $\mathrm{C}$ & $\mathrm{T}$ & $\mathrm{T}$ & $\mathrm{C}$ & $\mathrm{G}$ & $\mathrm{A}$ & $\mathrm{G}$ & $\mathrm{C}$ & $\mathrm{T}$ & $\mathrm{A}$ & $\mathrm{G}$ \\
Tensift & $\mathrm{T}$ & $\mathrm{G}$ & $\mathrm{T}$ & $\mathrm{C}$ & $\mathrm{T}$ & $\mathrm{T}$ & $\mathrm{C}$ & $\mathrm{G}$ & $\mathrm{A}$ & $\mathrm{G}$ & $\mathrm{C}$ & $\mathrm{T}$ & $\mathrm{A}$ & $\mathrm{G}$ \\
\hline
\end{tabular}

main axis of the maxilla, formed an angle greater than $135^{\circ}$, while in other trout populations from Morocco it was less than $135^{\circ}$ (Appendix 2).

\section{DESCRIPTION OF POPULATIONS OF GENUS SALMO FROM MOROCCO}

Our morphological and molecular analyses revealed that the population from Ifni Lake, recently described as a different species (Salmo akairos), had a high degree of distinct morphological features and moderate genetic differentiation in mitochondrial genes. The populations from the Oum er Rbia Basin showed scarce morphological and genetic differentiation relative to the Tensift Basin, where the species Salmo pellegrini was described (Delling \& Doadrio, 2005; Geiger et al., 2014); therefore we provisionally assigned populations from Oum er Rbia basins to Salmo pellegrini. However, one of the populations of this latter basin (Miaami Lagoon) showed differential morphological traits, particularly in the length and height of the maxilla and premaxilla bones, but it was nested within the Oum er Rbia Basin mitochondrial clade and therefore this population should be also provisionally assigned to $S$. pellegrini.

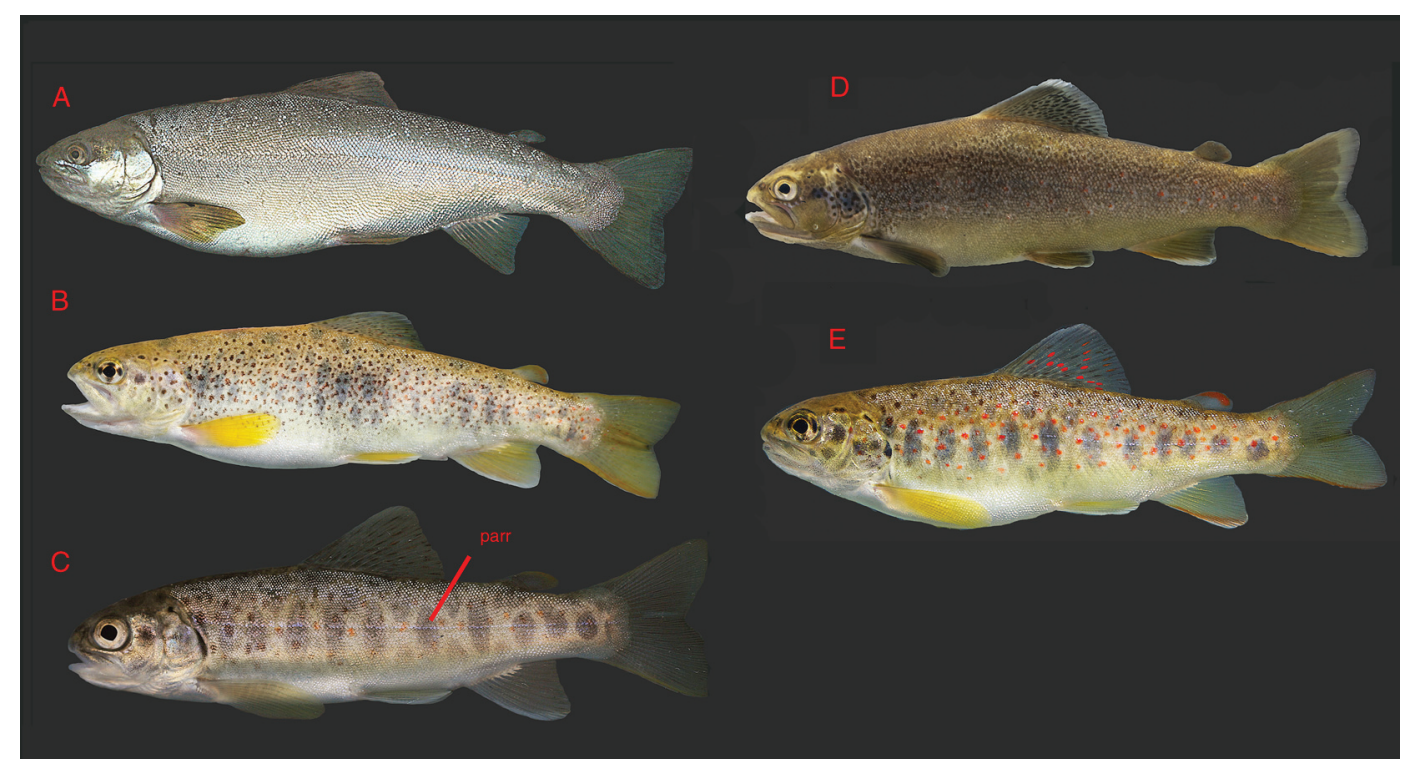

Fig. 5.- Isli, SL 222.6 mm (A), Dades, SL 128.5 mm (B), Ziz, SL 99.1 mm (C), Tensift, SL 200.9 mm (D) and Moulouya, SL $107.8 \mathrm{~mm}(\mathrm{E})$. Isli without parr marks and spots. Dades presents irregular and narrow parr marks in adults and multiple spots on the body. Ziz and Moulouya have large parr marks in adults. Tensift does not present parr marks in adults. parr=parr marks

Fig. 5.- Detalle del patrón de pigmentación en las poblaciones estudiadas de las truchas de Marruecos: Isli, SL $222.6 \mathrm{~mm}$ (A), Dades, SL 128.5 mm (B), Ziz, SL $99.1 \mathrm{~mm}$ (C), Tensift, SL $200.9 \mathrm{~mm}$ (D) and Moulouya, SL $107.8 \mathrm{~mm}$ (E). Isli no presenta las "rayas de pinto" ni manchas en el cuerpo. Dades presenta "rayas de pinto" irregulares y estrechas en los adultos y multiples puntos en el cuerpo. Poblaciones de Ziz y Moulouya tienen "rayas de pinto" grandes en los adultos. Los ejemplares adultos del Tendift no presentan "rayas de pinto". parr=parr marks. 
The populations of the Ziz and Moulouya basins showed moderate genetic differentiation for the MT-CYTB gene; genetic differences in allozyme markers had also been previously reported for the Ziz population (Lbadaoui et al., 2011). Nevertheless, no morphological differentiation was detected when compared to other populations from the Oum er Rbia Basin, and so in the absence of the inclusion of other Mediterranean populations in the morphological and genetic analyses, we named these two populations as Salmo sp. The populations from Isli Lake and the Dades Basin showed a high degree of morphological and genetic differentiation that justifies their consideration as distinct species. No available name for these populations exists at present, and therefore the two new species are described in this study.

\section{Salmo multipunctata Doadrio, Perea \& Yahyaoui, sp. nov.}

urn:1sid:zoobank.org:act:413738BC-A868-413A-937176EBCDB0A132

Holotype: Figure 6, Table 9. MNCN 290753, $126.3 \mathrm{~mm}$ (SL). Female. Dades River, Draa Basin, Ait Aatou O'Moussa (31.871776, -5.738205), Morocco; 21/10/2014. Collected by Doadrio, I; Yahyaoui, A; Garzón, P; Perea, S.

Paratypes: Table 9. MNCN 290751-290752, MNCN 290754290785: Thirty-four specimens from the Dades River, Draa Basin, Aït Aatou O'Moussa (31.871776, -5.738205), Morocco; 21/10/2014. Collected by Doadrio, I; Yahyaoui, A; Garzón P; Perea, S.

Holotype and a series of paratypes (35 specimens) have been deposited at the Fish Collection of the Museo Nacional de Ciencias Naturales, (Madrid, Spain).

DIAGNOSIS: Differs from other known species of the genus Salmo in the numerous irregular narrow parr marks, usually $\geq 14$, in the lateral line. Upper row of parr marks $\geq 10$. Lower row of parr marks variable, usually $\geq 5$. Two conspicuous black spots placed at the right and left sides of the iris and two less visible spots at the upper and lower sides of the iris. Numerous black, small spots placed at the upper side of the body and several red ocellated and non ocellated spots placed in middle of the body. Black spots sometimes extended to the opercular region and the caudal fin. Ethmoid bone with a characteristic $\mathrm{T}$ shape. Premaxilla bone with small and inclined upper process. From 14 to 16 (Median=14) scales from base of adipose fin to lateral line. From 12 to 14 dorsal fin pterygophores (Median=13). Nine molecular autopomorphies in $M T-C Y T B$ gene in the nucleotide positions $60,216,474,504,732,849,915,990,1090$.

DESCRIPTION: LL 104-112 ( $\bar{x}=108.5$ Median=108). RSA 14-16 ( $\bar{x}=14.3$; Median=14). AP 9-11 $(\bar{x}=10.3$, Median=10). AR iv 7-8 ( $\bar{x}=7.8$, Median=8). DP 12-14 $(\bar{x}=12.9$, Median=13). DR v(iv) 9-10 ( $\bar{x}=9.3$, Median=9). Bq 9-10 ( $\bar{x}=9.5$, Median=9.5). C 19. Cpr 10-13 ( $\bar{x}=11.5$, Median=11). Ve 53-55 ( $\bar{x}=54.1$, Median=54). It is a small-sized species that rarely reaches $250 \mathrm{~mm}$ standard length. The body is slightly more elongated in comparison to other trout populations, with maximum body depth, at the level of the anal origin, ranging from $16.1-18.7 \% \mathrm{SL}$ in females and $15.5-18.5 \% \mathrm{SL}$ in males. The head is large in relation to the body, in comparison to all trout populations except those of the Ifni and Miaami populations, with head length $22.6-24.9 \%$ SL in females and $23.7-25.8 \% \mathrm{SL}$ in males. The anterior part of the head shows a flat snout. The preorbital distance is the shortest of the populations studied and the proportion with respect to the head length is $18.6-20.7 \% \mathrm{HL}$ in females and $18.1-21.3 \% \mathrm{HL}$ in males. The fourth and fifth infraorbitals are narrow and sparsely extend over the hyomandibular bone (Fig. 7). The eye size in Salmo multipunctata and Salmo akairos is the largest in relation to other populations studied, and in Salmo multipunctata the horizontal diameter of the eye is $29.4-31.8 \% \mathrm{HL}$ in females and $28.5-33.5 \% \mathrm{HL}$ in males.

The supramaxilla is large and slender; its length is more than half of the maxilla. The maxilla is short and the proportion, with respect to the head length, is $46.3-53.2 \% \mathrm{SL}$ in females and $48.9-52.3 \% \mathrm{SL}$ in males. The upper jaw is deep as in the populations of the Ziz and Oum er Rbia river basins, except for the

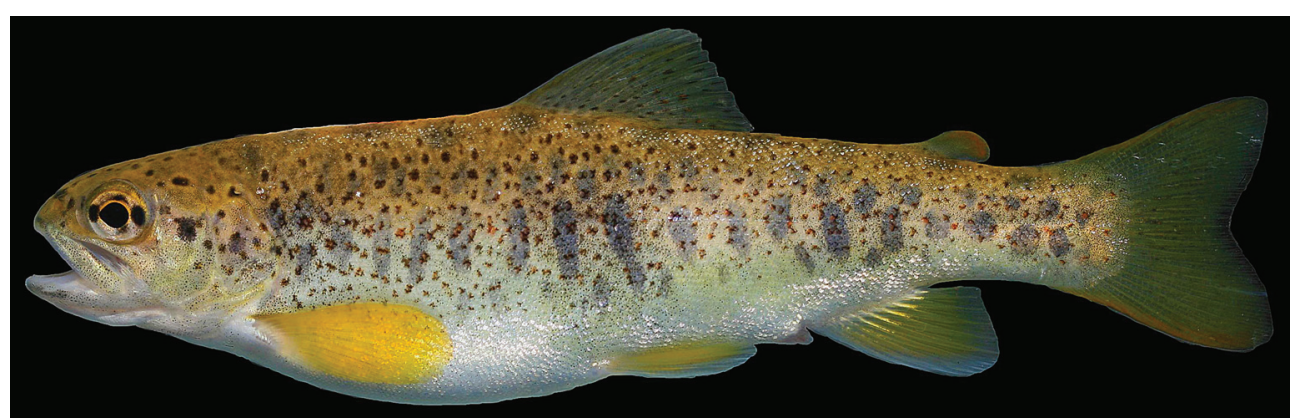

Fig. 6.- Holotype of Salmo multipunctata from the Dades River, Draa Basin, Aït Aatou O'Moussa, Morocco. MNCN 290753. SL $128.5 \mathrm{~mm}$.

Fig. 6.- Holotipo de Salmo multipunctata del río Dades, Cuenca del Draa, Aït Aatou O'Moussa, Marruecos. MNCN 290753. SL $128.5 \mathrm{~mm}$. 
Table 9.- Morphometric and meristic measurements of the holotype and paratypes of Salmo multipunctata.

Tabla 9.- Medidas morfométricas y merísticas del holotipo y paratipos de Salmo multipunctata.

\begin{tabular}{|c|c|c|c|c|}
\hline \multirow{2}{*}{$\begin{array}{l}\text { Morphometric } \\
\text { variables }\end{array}$} & \multirow{2}{*}{$\begin{array}{c}\text { Holotype MNCN } 290753 \\
\text { Measurement in } \mathrm{mm}\end{array}$} & \multicolumn{3}{|c|}{ Paratypes n=34 MNCN 290751-290752, 290754-290785 } \\
\hline & & Range & Mean & Standard Deviation \\
\hline SL & 128.5 & $161.7-52.5$ & 87.3 & 20.4 \\
\hline PrOL & 4.4 & $7-2.8$ & 4.4 & 1 \\
\hline EDH & 8.2 & $8.9-4.4$ & 5.7 & 0.9 \\
\hline EDV & 7.5 & 8-3.4 & 5.2 & 0.9 \\
\hline PsOL & 17.2 & $22.1-8.4$ & 13 & 2.8 \\
\hline HL & 29 & $35.7-15.5$ & 22.8 & 4.4 \\
\hline ML & 10.4 & $14.5-6$ & 8.5 & 2 \\
\hline UJL & 13.8 & $16.7-7$ & 10 & 2.2 \\
\hline UJD & 2.9 & 4.3-1.8 & 2.7 & 0.5 \\
\hline PrDD & 58.2 & $76.1-25.7$ & 41.3 & 9.3 \\
\hline PrPP & 25.3 & 30-13.2 & 19.4 & 3.4 \\
\hline PrVD & 65.7 & $82.9-29$ & 45.7 & 10.1 \\
\hline PrAD & 91 & $115.2-38.2$ & 62.2 & 14.4 \\
\hline CPL & 57.8 & $70.6-21.6$ & 37 & 9 \\
\hline CPA & 25.5 & $29.9-9.9$ & 17.8 & 4 \\
\hline PFL & 22.4 & $26.9-12.4$ & 18.4 & 3.2 \\
\hline DFL & 16.2 & 23.1-6.8 & 12.1 & 3.1 \\
\hline DFH & 23 & $29.2-10.6$ & 16.4 & 3.4 \\
\hline VFL & 16.8 & $24.9-8.3$ & 13.4 & 3 \\
\hline AFL & 15.3 & $19.2-5.6$ & 9.2 & 2.5 \\
\hline AFH & 22.1 & 29.1-9.7 & 14.9 & 3.7 \\
\hline CFL & 19.5 & $27.6-10.4$ & 15.3 & 3.3 \\
\hline BLD & 14.5 & $18-6.2$ & 10.2 & 2.2 \\
\hline BA & 24.1 & $31.9-9.2$ & 16.4 & 4.2 \\
\hline BD & 32.8 & 44.1-12 & 21.8 & 5.8 \\
\hline AP & 10 & $9-11$ & 10.3 & 0.7 \\
\hline DP & 13 & $12-14$ & 12.9 & 0.4 \\
\hline LL & 111 & $112-104$ & 108.5 & 2.1 \\
\hline RSA & 16 & 14-17 & 15.2 & 0.8 \\
\hline Ve & 53 & $53-55$ & 54.1 & 0.8 \\
\hline
\end{tabular}

Miaami population that has the significant deepest upper jaw. The maximum height of the upper jaw, in proportion to its length, is $33-38.4 \%$ UJL in females and $31.8-38.7 \%$ UJL in males. The caudal peduncle (CPL) is slightly deeper than in other populations, except that of Ifni Lake (S. akairos), and the proportion of the body at the least depth, with respect to caudal peduncle length, is $23.6-26.9 \%$ CPL in females and $24-28 \% \mathrm{CPL}$ in males. The teeth in vomer, premaxilla and glossohyal are very robust, as those of the Ziz and Moulouya populations.

The coloration is slightly yellow, lighter in the ventral area, and brownish in the dorsal region. The fins are slightly yellow with orange marginal borders of caudal and adipose fins. Dorsal, pelvic and anal fins in adults have white anterior edges. The dorsal fin presents a black line below the white mark. The dorsal fin has small black and red spots. Body with numerous small spots, which are black and slightly ocellated in the dorsal region and red spots (not ocellated) in the middle of the body. The iris has two black, conspicuous lateral spots and two less conspicuous above and below the iris. Parr marks are narrow, irregular and numerous, placed in the middle of body, sometimes divided into two marks. The species has a characteristic opercular black spot, and another spot just above it (usually ocellated). There are usually numerous black spots in the opercular area and the caudal fin. There are eight or nine black spots on the dorsal body, very conspicuous in juveniles, which tend to disappear in adults.

ETYMOLOGY: The species name "multipunctata" refers to its diagnostic pigmentation pattern, which is constituted by numerous spots and marks along the body. 


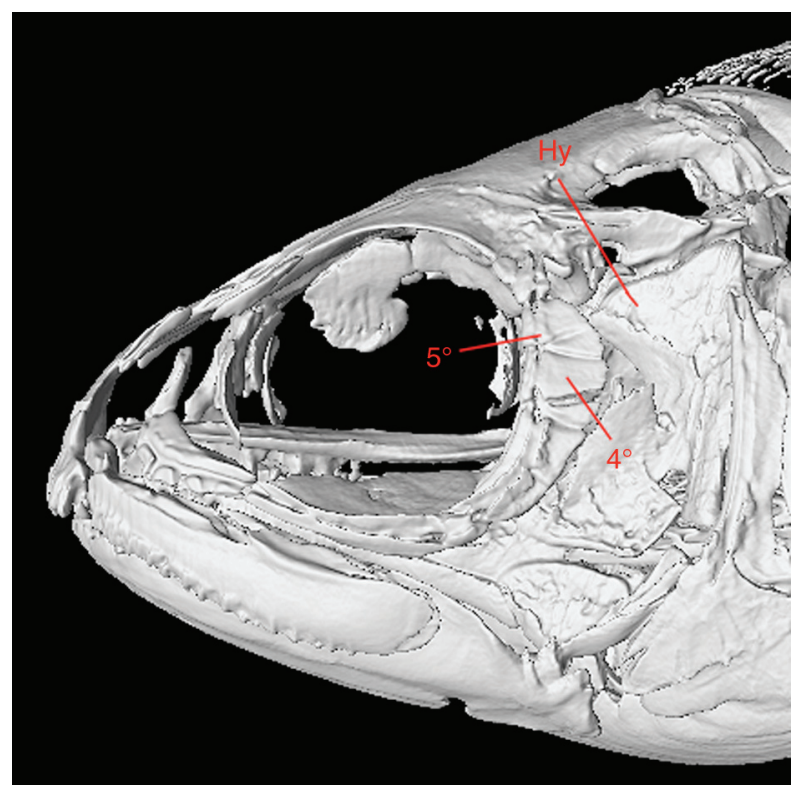

Fig. 7.- Narrow Infraorbital $4^{\circ}$ and $5^{\circ}$ not extended over the Hyomandibular (Hy). MNCN 290.754. SL. 98.5 mm.

Fig. 7.- Infraorbitales $4^{\circ}$ y $5^{\circ}$ estrechos que no se extienden por encima del hiomandibular (Hy). MNCN 290.754. SL. 98.5 mm.

DISTRIBUTION: This new species is endemic to the Draa Basin in southern Morocco, inhabiting the headwaters of the Dades and M'Goum rivers. In the Draa basin the species usually co-occurs with the cyprinid fish Luciobarbus lepineyi (Pellegrin, 1939).

COMMON NAME: We propose the English common name "Draa trout" for this species.

HABITAT AND BIOLOGY: Similar to other riverine trout of Morocco, this species inhabits small and shallow streams with clear and cold waters. No information about spawning season is available.

CONSERVATION: The habitat of this species suffers catastrophic seasonal floods that influence dramatically the demography of the population. The continuous deforestation of the Atlas Mountains and the disappearance of the riparian vegetation, increase the adverse effect of the overflows over the small Atlas rivers. Overfishing is also a problem for a small population such as the one from the Dades River. For this reason, we suggest that this species should be included in the IUCN category of Endangered (EN).

GENETICS: Uncorrected genetic distances between Salmo multipunctata and other studied populations of trout for the MT-CYTB gene ranged from 0.9 to $1.4 \%$. Salmo multipunctata is phylogenetically basal to $S$. trutta from Europe and other Salmo populations from Morocco assigned to $S$. akairos, S. pellegrini and S. macrostigma.
Salmo viridis Doadrio, Perea \& Yahyaoui, sp. nov.

urn:1sid:zoobank.org:act:A6209574-45BE-4A3E-BCB6DC21AFDC502C

Holotype: Figure 8, Table 10. MNCN 280413, $254.1 \mathrm{~mm}$ (SL), Male. Isli Lake, Imilchil (32.217526, -5.548031), Morocco; 30/10/2009. Collected by Doadrio, I; Yahyaoui, A; Garzón, P; Cuerva, I.

Paratypes: Table 10. MNCN 281050-281067: Eighteen specimens from Isli Lake, Imilchil (32.217526, -5.548031), Morocco; 31/10/2011. Collected by M. Esteve and F. Melero. MNCN 280414: One specimen from Isli Lake, Imilchil (32.217526, -5.548031) Morocco; 30/10/2009. Collected by (Coll.) Doadrio, I; Yahyaoui, A; Garzón P; Cuerva, I.

Holotype and a series of paratypes (20 specimens) have been deposited at the Fish Collection of the Museo Nacional de Ciencias Naturales, (Madrid, Spain).

DIAGNOSIS: Differs from other known species of the genus Salmo from Morocco (except Salmo pallaryi) by the absence of spots or marks on the body. The species Salmo viridis has a lesser number of anal pterygophores (AP 10-11; Median=10) than Salmo pallaryi (AP 12-14; Median=13) and shorter orbital length. Horizontal orbital length with respect to the head length is $16-23 \%$ HL in Salmo viridis vs $25-31 \%$ HL in Salmo pallaryi. The following combination of characters are also diagnostic to Salmo viridis: Vomer teeth in one row, premaxilla extended laterally, supramaxilla short and deep, dorsal fin pterygophores from 11 to 13 (Median=12). One molecular autapomorphy in the MT-CYTB gene in the nucleotide position 508 .

DESCRIPTION: LL 105-116 ( $\bar{x}=109.4$; Median=108). RSA 15-18 ( $\bar{x}=16.9$; Median=17). AP 10-11 $(\bar{x}=10.3$, Median=10). AR iv 7-8 (x=7.6, Median=8). DP 11-13 ( $\bar{x}=11.7$, Median=12). DR v(vi) 9-10 ( $\bar{x}=9.7$, Median=10). Bq 8-11 ( $\bar{x}=9.2$; Median=9). C 19. Ve $53-55(\bar{x}=54.4$, Median $=54)$. It is a large-sized species that reaches $500 \mathrm{~mm}$ of standard length. The caudal peduncle is more elongated, in comparison to other trout populations, and the proportion of body to least depth, with respect to caudal peduncle length, is $25.3-26 \%$ CPL in females and $23.5-27.1 \%$ CPL in males. In comparison to all trout populations the head is small, relative to the body, with head length $21.7-24.4 \% \mathrm{SL}$ in females and $21.4-24.8 \%$ SL in males. The skull is narrow with a pointed snout. The preorbital distance is the largest, compared to the populations studied, and the proportion, with respect to head length, is $26-31 \%$ $\mathrm{HL}$ in females and $21.6-34 \% \mathrm{HL}$ in males. The fourth and fifth infraorbitals are wide and extended over the hyomandibular bone (Fig. 9).

The supramaxilla is short and deep. The length of the maxilla is variable in this species and usually reaches the edge of the posterior eye orbit (Fig. 10). The length of the maxilla, in proportion and with respect to head length is $44.4-56.3 \%$ SL in females and $46.5-52.8 \%$ $\mathrm{SL}$ in males. The upper jaw is narrower than in other populations except that of Ifni Lake, which belongs to 


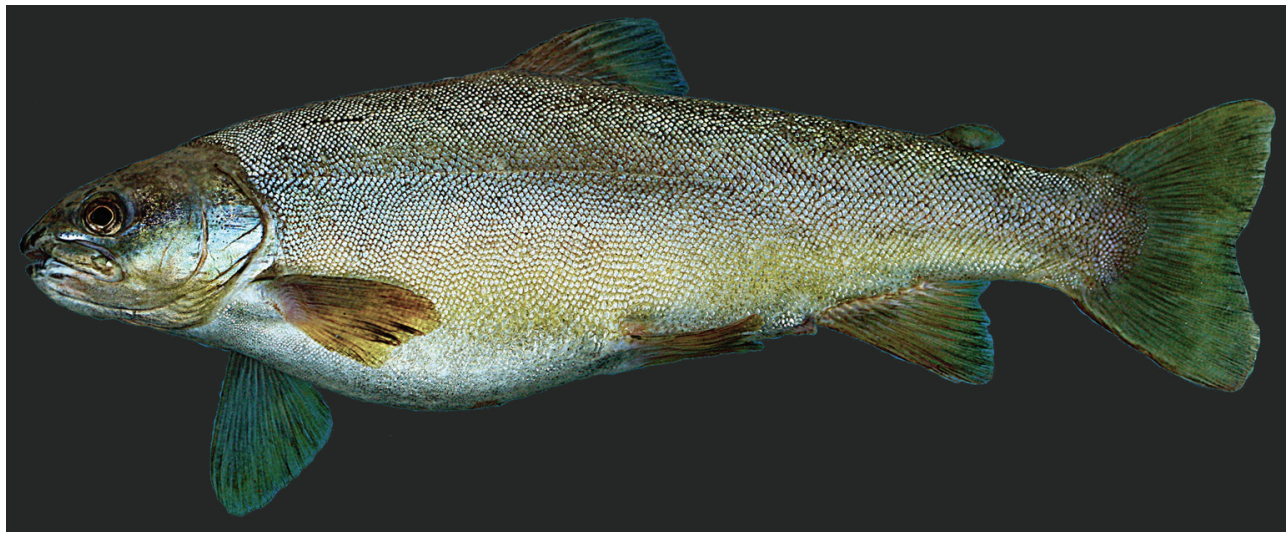

Fig. 8.- Holotype of Salmo viridis from Isli Lake, Imilchil, Morocco. MNCN 280413. SL $254.1 \mathrm{~mm}$.

Fig. 8.- Holotipo de Salmo viridis del Lago de Isli, Imilchil, Marruecos. MNCN 280413. SL 254.1 mm.

Table 10.- Morphometric and meristic measurements of the holotype and paratypes of Salmo viridis.

Tabla 10.- Medidas morfométricas y merísticas del holotipo y paratipos de Salmo viridis.

\begin{tabular}{|c|c|c|c|c|}
\hline \multirow{2}{*}{$\begin{array}{l}\text { Morphometric } \\
\text { variables }\end{array}$} & \multirow{2}{*}{$\begin{array}{c}\text { Holotype MNCN } 280413 \\
\text { Measurement in } \mathrm{mm}\end{array}$} & \multicolumn{3}{|c|}{ Paratypes n=21 MNCN 280414, 281050-281067 } \\
\hline & & Range & Mean & Standard Deviation \\
\hline SL & 254.1 & $430-186.2$ & 277.7 & 60.6 \\
\hline PrOL & 15.9 & $35.4-10.7$ & 18.4 & 6.4 \\
\hline EDH & 11.5 & $16.5-9.4$ & 11.8 & 1.9 \\
\hline EDV & 10.1 & $14.3-8.2$ & 10.9 & 1.6 \\
\hline PsOL & 35.2 & $54.3-23.9$ & 35.2 & 7.9 \\
\hline HL & 61.3 & $103.3-42.4$ & 64.7 & 15.5 \\
\hline ML & 24.0 & $42.7-16.9$ & 26.9 & 7.0 \\
\hline UJL & 28.5 & $55.1-20.2$ & 33.2 & 9.1 \\
\hline UJD & 6.9 & $10.5-5.4$ & 7.6 & 1.3 \\
\hline PrDD & 121.3 & $177.7-93.3$ & 120.9 & 22.8 \\
\hline PrPP & 57.6 & $89.2-37.2$ & 59.7 & 13.3 \\
\hline PrVD & 147.6 & 221-97.5 & 143.3 & 29.1 \\
\hline PrAD & 192.7 & 298.7-130 & 195.6 & 41.3 \\
\hline CPL & 113.6 & $185.6-94.1$ & 123.8 & 22.1 \\
\hline CPA & 59.4 & $88.3-44.9$ & 61.3 & 10.7 \\
\hline APL & 46.5 & $72.7-37.6$ & 51.2 & 9.3 \\
\hline PFL & 40.5 & $71.6-35.7$ & 48.6 & 10.6 \\
\hline DFL & 32.5 & $59.8-25.4$ & 38.4 & 9.2 \\
\hline DFH & 42.2 & 69-34 & 47.8 & 9.6 \\
\hline VFL & 33.1 & $53.8-26.2$ & 36.3 & 7.6 \\
\hline AFL & 29.2 & $47.1-17.4$ & 29.1 & 6.9 \\
\hline AFH & 38.8 & $59.9-28.4$ & 41.2 & 7.3 \\
\hline CFL & 46.0 & $64.3-34.1$ & 44.3 & 8.2 \\
\hline BLD & 25.6 & $40.2-18.9$ & 26.8 & 5.6 \\
\hline BA & 54.1 & $76.1-36.3$ & 51.4 & 10.7 \\
\hline BD & 64.3 & $100.9-48.4$ & 70.5 & 15.6 \\
\hline AP & - & 10-11 & 10.3 & 0.5 \\
\hline DP & - & 11-13 & 11.7 & 0.7 \\
\hline LL & 108 & 116-105 & 108 & 3.2 \\
\hline RSA & 16 & 15-18 & 17 & 0.9 \\
\hline Ve & - & $53-55$ & 54.5 & 0.7 \\
\hline
\end{tabular}




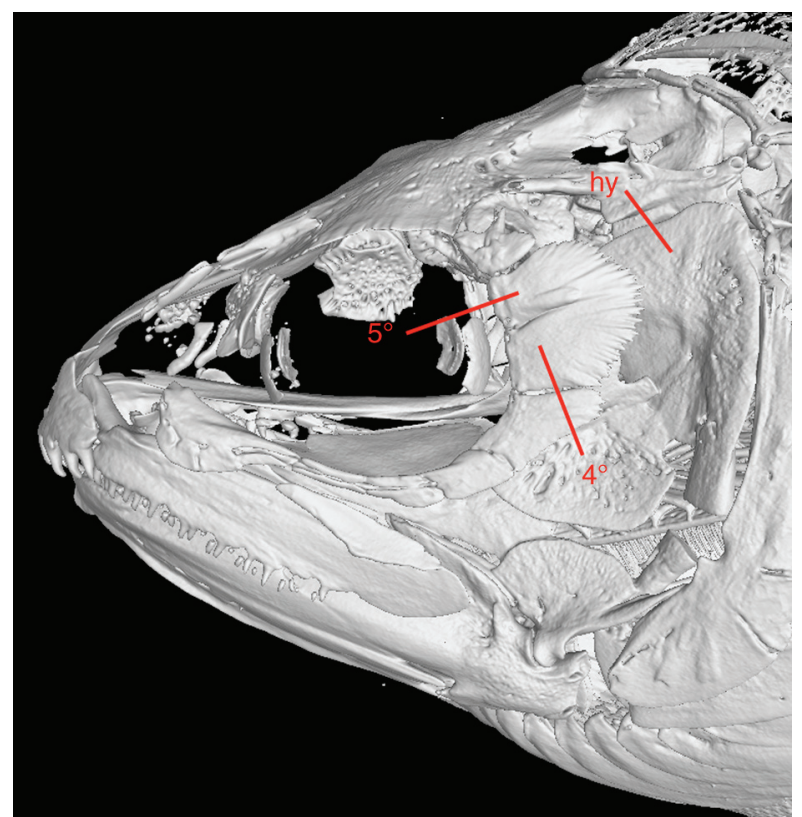

Fig. 9.- Wide Infraorbital $4^{\circ}$ and $5^{\circ}$ extended over the Hyomandibular (hy). MNCN 280414. SL $222.6 \mathrm{~mm}$.

Fig. 9.- Infraorbitales $4^{\circ}$ y $5^{\circ}$ anchos que se extienden por encima del hiomandibular (hy). MNCN 280414. SL 222.6 mm.

S. akairos. The maximum height of the upper jaw, in proportion to its length, is $28.4-33.1 \%$ UJL in females and $24.6-32.2 \%$ UJL in males. The eye orbit is small, in proportion to head length, the horizontal diameter being $17.5-19.4 \% \mathrm{HL}$ in females and $15.6-22.8 \% \mathrm{HL}$ in males and the vertical diameter being $16.4-19.8 \%$ HL in females and 13.8-20\% HL in males (Fig. 10). The vomer teeth are placed in one row and are small and thin.

The coloration is uniformly grayish with some greenish iridizations, paler in the ventral region. The pectoral fins are slightly yellow and caudal, adipose and anal fins are greenish. No spot or marks are found, only some traces in caudal fin and dorsal skull.
ETYMOLOGY: The species name "viridis" refers to its diagnostic greenish coloration in some parts of body and fins.

DISTRIBUTION: This new species is endemic to Isli Lake in the Atlas Mountains of Morocco. It is the only fish species inhabiting this lake.

COMMON NAME: We propose the English common name "green trout" for this species.

HABITAT AND BIOLOGY: This species inhabits the Isli Lake (Fig. 11). Isli is situated on a high plateau, 2270 meters above sea level. It is a large and deep $(\approx 2 \mathrm{~km}$ of diameter, $92 \mathrm{~m}$ deep) oligotrophic lake. The geological origin of this Lake is under debate. Some authors point to its origin as a consequence of a meteorite impact that occurred approximately 40000 years ago (Ibhi et al., 2013; Nachit et al., 2013), while others consider a tectonic origin during the Pleistocene period, similar to the one proposed for other Moroccan lakes (Chaabout et al., 2013). The presence of a natural population of Salmo viridis in Isli Lake is in agreement with the latter hypothesis. The spawning of this species takes place at the end of October and November in the sandy beaches of the lake.

CONSERVATION: The habitat of this species is threatened due to eutrophication, related to intensive overpasture. Overfishing is also a problem due to the low protection of the lake. No juveniles have been observed in the last years and several malformations in fins and skull were observed in this population. For this reason, we suggest that this species should be included in the IUCN category of Endangered (EN).

GENETICS: Uncorrected genetic distances between Salmo viridis and other studied populations of trout for the MT-CYTB gene ranged from 0.2 to $1 \%$. The

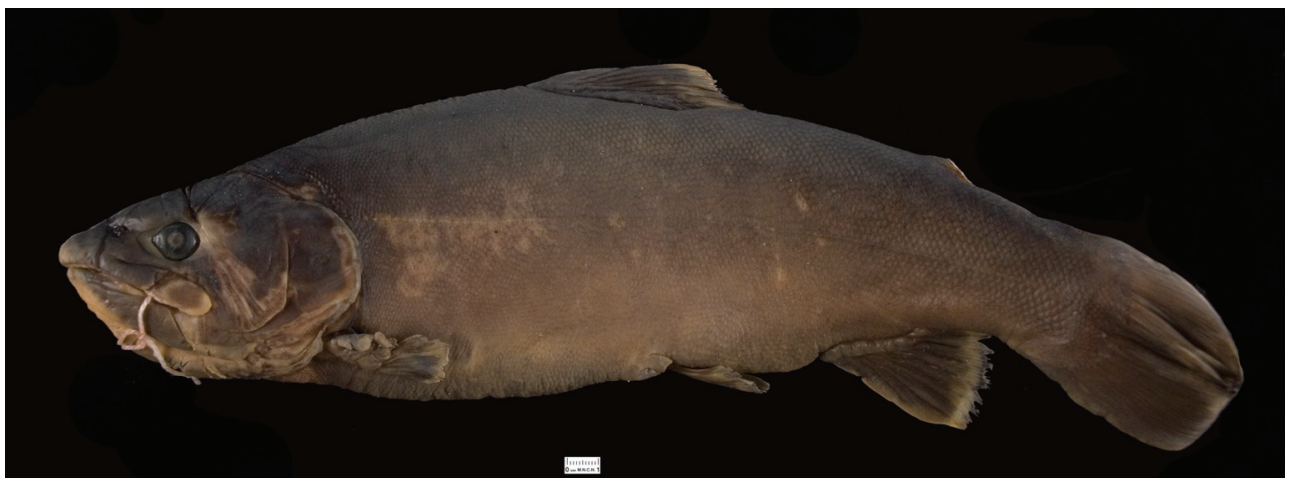

Fig. 10.- Male of $333.5 \mathrm{~mm}$ SL from Isli Lake (MNCN 281058) shows some typical traits of Salmo viridis: small eye, pointed snout and maxilla extended to postorbital edge.

Fig. 10.- Macho de $333.5 \mathrm{~mm}$ SL del lago de Isli (MNCN 281058) mostrando algunos caracteres típicos de Salmo viridis. Ojo pequeño, hocico puntiagudo y maxilar extendiéndose al borde posterior del ojo. 


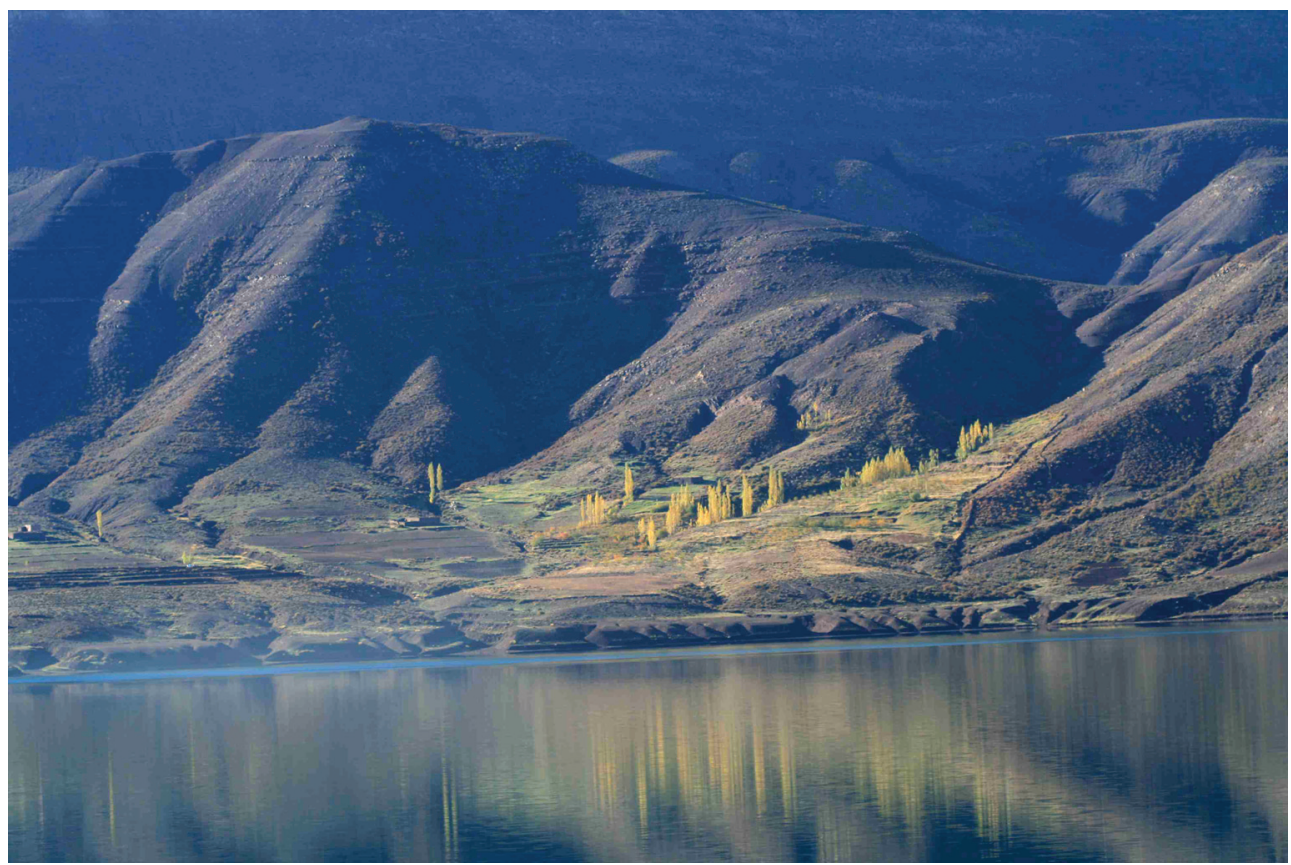

Fig. 11.- Isli Lake, a large and deep lake where Salmo viridis lives.

Fig. 11.- Lago de Isli, un lago extenso y profundo donde vive Salmo viridis.

divergence degree is similar to that of Salmo akairos in comparison to other populations inhabiting Atlas lakes.

\section{Acknowledgments}

Many persons have participated in the field sampling trips. We warmly thank L. Bensadon, M. Casal, A. Doadrio, I. Doadrio jr., M. Esteve, P. Garzón, I. Hortelano, F. Melero and I. Zourir. We would also like to thank L. Alcaraz, involved in lab work, the curator of the ichtyological collection of the National Museum of the Natural Sciences (MNCN-CSIC), G. Solis, and also C. Parejo for her technical assistance at the lab of nondestructive techniques with the computerized Tomography scan (CTscan) at the MNCN-CSIC. We also thank E. González for the English grammar corrections. This study was supported by the MESRSFC and CNRST from Morocco under grant $\mathrm{N}^{\circ}$ PPR/2015/2 for the project "Impact des changements climatiques sur la diversité génétique des poissons des eaux douces du Maroc". The High Commissioner for Water, Forests and Fight Against Dessertification of Morocco provided permission for fish collection.

\section{References}

Akaike, H., 1973. Information theory and an extension of the Maximum Likelihood principle. In: B.N. Petrov \& F. Csaki (eds). Proceedings of the second International Symposium on Information Theory. Akademini Kiado. Budapest: 267-281.

Bernatchez, L., 2001. The evolutionary history of brown trout (Salmo trutta L.) inferred from phylogeographic, nested clade, and mismatch analyses of mitochondrial DNA variation. Evolution, 55: 351-379. http://dx.doi. org/10.1111/j.0014-3820.2001.tb01300.x
Burnaby, T. P., 1966. Growth-invariant discriminant functions and generalized distances. Biometrics, 22: 96-110. http://dx.doi.org/10.2307/2528217

Chaabout, S., Chennaoui-Aoudjehane, H., Reimold, W. U., Aboulahris, M. \& Aoudjehane, M. M., 2013. Evidence of non-impact cratering origin of Imilchil (Morocco) lakes (Isli and Tislit). In: Large Meteorite Impacts and Planetary Evolution V, Sudbury. Lunar and Planetary Institute Contribution, 1737: 3074.

Cortey, M., Pla, C. \& Garcia-Marin, J. L., 2004. Historical biogeography of Mediterranean trout. The role of allopatry and dispersal events. Molecular Phylogenetics and Evolution, 33: 831-844. http://dx.doi.org/10.1016/j. ympev.2004.08.012

Delling, B., 2002. Morphological distinction of the marble trout, Salmo marmoratus, incomparison to marbled Salmo trutta from River Otra, Norway. Cybium, 26: $283-300$

Delling, B., 2003. Species Diversity and Phylogeny of Salmo with Emphasis on Southern Trouts (Teleostei, Salmonidae). PhD thesis. Department of Zoology, Stockholm University. Stockholm.

Delling, B., 2010. Diversity of western and southern Balkan trouts, with the description of a new species from the Louros River, Greece (Teleostei, Salmonidae). Ichthyological Exploration of Freshwaters, 21: 331-344.

Delling, B. \& Doadrio, I., 2005. Systematics of the trouts endemic to Moroccan lakes, with description of a new species (Teleostei: Salmonidae). Ichthyological Exploration of Freshwaters, 16: 49-64.

Geiger, M. F., Herder, F., Monaghan, F. T., Almada, V., Barbieri, R., Bariche, M., Berrebi, P., Bohlen, J., CasalLopez, M., Delmastro, G. B., Denys, G. P. J., Dettai, A., Doadrio, I., Kalogianni, E., Kärst, H., Kottelat, A., 
Kovačić, M., Laporte, M., Lorenzoni, M., Marčić, Z., Özuluğ, M., Perdices, A., Perea, S., Persat, H., Porcelotti, S., Puzzi, C., Robalo, J., Šanda, R., Schneider, M., Šlechtová, V., Stumboudi, M., Walter, S. \& Freyhof, J., 2014. Spatial heterogeneity in the Mediterranean biodiversity hotspot affects barcoding accuracy of its freshwater fishes. Molecular Ecology Resources, 14: 1210-1221. http://dx.doi.org/10.1111/1755-0998.12257

Hammer, Ø., Harper, D. A. T. \& Ryan, D., 2001. PAST: Paleontological Statistics Software Package for Education and Data Analysis. Paleontological Electronica, 41(1): 9 pp.

Ibhi, A., Nachit, H., Abia, E. H., Ait Touchnt, A. \& Vaccaro, C., 2013. Isli and Tislit: the first dual impact crater discovered in Morocco. International Journal of Astronomy and Astrophysics, 3: 1-4. http://dx.doi.org/10.4236/ ijaa.2013.32A001

Kottelat, M. \& Freyhof, J., 2007. Handbook of European Freshwater Fishes. Publications Kottelat. Cornol. 646 pp.

Lanfear, R., Calcott, B., Ho, S. Y. W. \& Guindon, S., 2012. PartitionFinder: combined selection of partitioning schemes and substitution models for phylogenetic analyses. Molecular Biology and Evolution, 29(6): 1695-1701. http://dx.doi.org/10.1093/molbev/mss020

Lbadaoui, K., Nouiri, H. \& Jarizi, H., 2011. Les populations Marocaines autochtones des truites du genre Salmo: variation allozymique et statut taxinomique. Lebanese Science Journal, 12(2): 13-23.

Machordom, A. \& Doadrio, I., 2001. Evidence of a CenozoicBetic-Kabilian connection based on freshwater fish phylogeography (Luciobarbus, Cyprinidae). Molecular Phylogenetics and Evolution, 18: 252-263. http://dx.doi. org/10.1006/mpev.2000.0876

Machordom, A., Suárez, J., Almodóvar, A. \& Bautista, J. M., 2000. Mitochondrial haplotype variation and phylogeography of Iberian brown trout populations. Molecular Ecology, 9: 1325-1338. http://dx.doi.org/10. 1046/j.1365-294x.2000.01015.x

Nachit, H., Ibhi A. \& Vaccaro, C., 2013. The Imilchil meteorite strewn field Isli-Agoudal craters. International Letters of Chemistry, Physics and Astronomy, 11: 65-71. http:// dx.doi.org/10.18052/www.scipress.com/ILCPA.16.65

Rohlf, F. J. \& Bookstein, F. L., 1987. A comment on shearing as a method for "size correction". Systematic Zoology, 36: 356-367.

Ronquist, F., Teslenko, M., van der Mark, P., Ayres, D. L., Darling, A., Höhna, S., Larget, B., Liu, L., Suchard, M. A.
\& Huelsenbeck, J. P., 2012. MrBayes 3.2: Efficient Bayesian Phylogenetic Inference and Model Choise Across Large Model Space. Systematic Biology, 61(3): 539-542. http://dx.doi.org/10.1093/sysbio/sys029

Schöffmann, J., 1993. Autochthone Forellen (Salmo trutta L.) in Nordafrika. Österreichs Fischerei, 46: 164-169.

Shedko S. V., Miroshnichenko, I. L. \& Nemkova, G. A., 2013. Phylogeny of Salmonids (Salmoniformes: Salmonidae) and its Molecular Dating: Analysis of mtDNA Data. Russian Journal of Genetics, 49(6): 623-637. http://dx.doi. org/10.1134/S1022795413060112

Snoj, A., Marić, S., Bajec, S. S., Berrebi, P., Janjani, S. \& Schöffmann, J., 2011. Phylogeographic structure and demographic patterns of brown trout in North-West Africa. Molecular Phylogenetics and Evolution, 61(1): 203-211. http://dx.doi.org/10.1016/j.ympev.2011.05.011

Suárez, J., Bautista, J. M., Almodóvar, A. \& Machordom, A., 2001. Evolution of the mitochondrial control region in Palearctic brown trout (Salmo trutta) populations: the biogeographical role of the Iberian Peninsula. Heredity, 87: 198-206.

Tamura, K., Stecher, G., Peterson, D., Filipski, A. \& Kumar, S., 2013. MEGA6: Molecular Evolutionary Genetics Analysis (MEGA) Software version 6.0. Molecular Biology and Evolution, 24(8): 1596-1599.

Turan, D., Doğan, E., Kaya, M. \& Kanyılmaz, M. C., 2014 b. Salmo kottelati, a new species of trout from Alakır Stream, draining to the Mediterranean in southern Anatolia, Turkey (Teleostei, Salmonidae). ZooKeys, 462: 8177. http://dx.doi.org/10.3897/zookeys.462.8177

Turan, D., Kottelat, M. \& Engin, S., 2010. Two new species of trouts, resident and migratory, sympatric in streams of northern Anatolia (Salmoniformes: Salmonidae). Ichthyological Exploration of Freshwaters, 20(4): 289-384.

Turan, D., Kottelat, M. \& Bekta, Y., 2011. Salmo tigridis, a new species of trout from the Tigris River, Turkey (Teleostei: Salmonidae). Zootaxa, 2993: 23-33.

Turan, D., Kottelat, M. \& Engin, S., 2012. The trouts of the Mediterranean drainages of southern Anatolia, Turkey, with description of three new species (Teleostei: Salmonidae). Ichthyological Exploration of Freshwaters, 23: 219-236.

Turan, D., Kottelat, M. \& Engin, S., 2014a. Two new species of trouts from the Euphrates drainage, Turkey (Teleostei: Salmonidae). Ichthyological Exploration of Freshwaters, 24: 275-287. 
Appendix 1.- Non-parametric Kruskal-Wallis tests and Mann-Whitney's post hoc comparisons, for all populations. Values of Kruskal-Wallis test below variables. Values of Mann-Whiney test below diagonal. Medians in the diagonal. Significant differences $p<0.01\left(^{*}\right)$. Abbreviations are described in the Material and Methods epigraph.

Apéndice 1.- Test no paramétrico de Kruskal-Wallis y comparaciones post hoc de Mann-Whitney para todas las poblaciones. Valores para el test de Kruskal-Wallis debajo de las variables. Valores de Mann-Whitney por debajo de la diagonal. Valor de la mediana en la diagonal. Diferencias significativas $p<0.01\left(^{*}\right)$. Las abreviaturas están descritas en el epígrafe de Material y Métodos.

\begin{tabular}{|c|c|c|c|c|c|c|c|c|c|c|}
\hline $\begin{array}{l}\text { Variables } \\
\text { (H statistic) }\end{array}$ & Populations & $\begin{array}{c}\mathrm{Ziz} \\
\mathrm{N}=8\end{array}$ & $\begin{array}{c}\text { Dades } \\
\mathrm{N}=23\end{array}$ & $\begin{array}{c}\text { Lahkdar } \\
\mathrm{N}=22\end{array}$ & $\begin{array}{c}\text { Melloul } \\
\mathbf{N}=\mathbf{2 0}\end{array}$ & $\begin{array}{c}\text { Miaami } \\
\mathrm{N}=14\end{array}$ & $\begin{array}{c}\text { Isli } \\
\mathrm{N}=15\end{array}$ & $\begin{array}{c}\text { Ifni } \\
\mathrm{N}=17\end{array}$ & $\begin{array}{c}\text { Moulouya } \\
\mathrm{N}=12\end{array}$ & $\begin{array}{c}\text { Tensift } \\
\mathrm{N}=11\end{array}$ \\
\hline \multirow{9}{*}{$\begin{array}{l}\mathrm{SL} \\
\left(\mathrm{H}=86.49^{*}\right)\end{array}$} & Ziz & 103.5 & & & & & & & & \\
\hline & Dades & 0.35 & 84.2 & & & & & & & \\
\hline & Lakhdar & 0.13 & $0.001^{*}$ & 118 & & & & & & \\
\hline & Melloul & 0.16 & $0.002^{*}$ & 0.8 & 114 & & & & & \\
\hline & Miaami & 0.10 & $0.001^{*}$ & 0.82 & 0.81 & 115.8 & & & & \\
\hline & Isli & $0.001^{*}$ & $0.001^{*}$ & $0.001^{*}$ & $0.001^{*}$ & $0.001^{*}$ & 278.5 & & & \\
\hline & Ifni & $0.003^{*}$ & $0.001^{*}$ & $0.01^{*}$ & $0.01^{*}$ & $0.002^{*}$ & $0.001^{*}$ & 131.9 & & \\
\hline & Mouloya & $0.004^{*}$ & $0.001^{*}$ & $0.01^{*}$ & $0.004^{*}$ & $0.01^{*}$ & $0.001^{*}$ & 0.13 & 148.7 & \\
\hline & Tensift & $0.003^{*}$ & $0.001^{*}$ & $0.001^{*}$ & $0.001^{*}$ & $0.001^{*}$ & $0.001^{*}$ & $0.004^{*}$ & 0.44 & 158.2 \\
\hline \multirow{9}{*}{$\begin{array}{l}\text { SL/PrOL } \\
\left(H=105.2^{*}\right)\end{array}$} & $\mathrm{Ziz}$ & 21.5 & & & & & & & & \\
\hline & Dades & 0.18 & 20.9 & & & & & & & \\
\hline & Lakhdar & $0.004^{*}$ & $0.01^{*}$ & 20.2 & & & & & & \\
\hline & Melloul & $0.001^{*}$ & $0.001^{*}$ & 0.04 & 19.3 & & & & & \\
\hline & Miaami & $0.001^{*}$ & $0.001^{*}$ & $0.001^{*}$ & $0.001^{*}$ & 13 & & & & \\
\hline & Isli & $0.001^{*}$ & $0.001^{*}$ & $0.001^{*}$ & $0.001^{*}$ & $0.001^{*}$ & 15.7 & & & \\
\hline & Ifni & $0.001^{*}$ & $0.001^{*}$ & $0.001^{*}$ & 0.05 & $0.001^{*}$ & $0.002^{*}$ & 18.3 & & \\
\hline & Mouloya & 0.78 & 0.06 & $0.003^{*}$ & $0.001^{*}$ & $0.001^{*}$ & $0.001^{*}$ & $0.001^{*}$ & 21.5 & \\
\hline & Tensift & 0.71 & $0.03^{*}$ & $0.001^{*}$ & $0.001^{*}$ & $0.001^{*}$ & $0.001^{*}$ & $0.001^{*}$ & 0.926 & 21.6 \\
\hline \multirow{9}{*}{$\begin{array}{l}\text { SL/EDH } \\
\left(H=102.9^{*}\right)\end{array}$} & Ziz & 14.1 & & & & & & & & \\
\hline & Dades & $0.02^{*}$ & 13.1 & & & & & & & \\
\hline & Lakhdar & $0.001^{*}$ & $0.001^{*}$ & 16.1 & & & & & & \\
\hline & Melloul & $0.001^{*}$ & $0.001^{*}$ & $0.002^{\star}$ & 17.3 & & & & & \\
\hline & Miaami & $0.003^{*}$ & $0.001^{*}$ & 0.02 & 0.30 & 18.4 & & & & \\
\hline & Isli & $0.001^{*}$ & $0.001^{*}$ & $0.001^{*}$ & $0.001^{*}$ & $0.001^{\star}$ & 23.2 & & & \\
\hline & Ifni & 0.31 & 0.81 & $0.001^{*}$ & $0.001^{*}$ & $0.001^{*}$ & $0.001^{*}$ & 13.6 & & \\
\hline & Mouloya & $0.01^{*}$ & $0.001^{*}$ & 0.34 & $0.001^{*}$ & $0.01^{*}$ & $0.001^{*}$ & $0.001^{*}$ & 15.8 & \\
\hline & Tensift & $0.007^{\star}$ & $0.001^{*}$ & $0.014^{*}$ & $0.001^{*}$ & $0.002^{*}$ & $0.001^{*}$ & $0.013^{\star}$ & $0.002^{*}$ & 14.9 \\
\hline \multirow{9}{*}{$\begin{array}{l}\text { SL/EDV } \\
\left(H=103.2^{*}\right)\end{array}$} & Ziz & 15.6 & & & & & & & & \\
\hline & Dades & 0.10 & 15.3 & & & & & & & \\
\hline & Lakhdar & 0.01 & $0.001^{*}$ & 18.5 & & & & & & \\
\hline & Melloul & $0.003^{*}$ & $0.001^{*}$ & $0.003^{*}$ & 20.4 & & & & & \\
\hline & Miaami & $0.001^{*}$ & $0.001^{*}$ & 0.03 & 0.55 & 20 & & & & \\
\hline & Isli & $0.001^{*}$ & $0.001^{*}$ & $0.001^{*}$ & $0.001^{*}$ & $0.001^{*}$ & 25.4 & & & \\
\hline & Ifni & $0.001^{*}$ & 0.07 & $0.001^{*}$ & $0.001^{*}$ & $0.001^{*}$ & $0.001^{*}$ & 15 & & \\
\hline & Mouloya & $0.01^{*}$ & $0.001^{*}$ & 0.601 & $0.03^{*}$ & 0.113 & $0.001^{*}$ & $0.001^{*}$ & 18.9 & \\
\hline & Tensift & $0.004^{*}$ & $0.001^{*}$ & 0.745 & $0.007^{*}$ & $0.048^{*}$ & $0.001^{*}$ & $0.001^{*}$ & 0.735 & 18.8 \\
\hline \multirow{9}{*}{$\begin{array}{l}\text { SL/PsOL } \\
(\mathbf{H = 8 3 . 0 3 )}\end{array}$} & Ziz & 7.9 & & & & & & & & \\
\hline & Dades & 0.38 & 8.1 & & & & & & & \\
\hline & Lakhdaar & 0.53 & 0.81 & 8.1 & & & & & & \\
\hline & Melloul & $0.001^{*}$ & $0.001^{*}$ & $0.001^{*}$ & 7.3 & & & & & \\
\hline & Miaami & $0.001^{*}$ & $0.001^{*}$ & $0.001^{*}$ & $0.001^{*}$ & 6.7 & & & & \\
\hline & Isli & 0.88 & 0.06 & 0.13 & $0.001^{*}$ & $0.001^{*}$ & 7.9 & & & \\
\hline & Ifni & 0.54 & $0.007^{\star}$ & 0.10 & $0.001^{*}$ & $0.001^{*}$ & 0.97 & 7.8 & & \\
\hline & Mouloya & 0.07 & $0.001^{*}$ & $0.006^{*}$ & 0.162 & $0.001^{*}$ & 0.063 & 0.097 & 7.5 & \\
\hline & Tensift & 0.003 & $0.001^{*}$ & $0.001^{*}$ & 0.667 & $0.001^{*}$ & $0.002^{*}$ & $0.001^{*}$ & 0.166 & 7.3 \\
\hline
\end{tabular}


Appendix 1.- (Continued)

\begin{tabular}{|c|c|c|c|c|c|c|c|c|c|c|}
\hline $\begin{array}{l}\text { Variables } \\
\text { (H statistic) }\end{array}$ & Populations & $\begin{array}{c}\mathrm{Ziz} \\
\mathrm{N}=8\end{array}$ & $\begin{array}{l}\text { Dades } \\
\mathrm{N}=23\end{array}$ & $\begin{array}{c}\text { Lahkdar } \\
\mathrm{N}=22\end{array}$ & $\begin{array}{c}\text { Melloul } \\
\mathbf{N}=\mathbf{2 0}\end{array}$ & $\begin{array}{c}\text { Miaami } \\
\mathrm{N}=14\end{array}$ & $\begin{array}{c}\text { Isli } \\
\mathrm{N}=15\end{array}$ & $\begin{array}{c}\text { Ifni } \\
\mathrm{N}=17\end{array}$ & $\begin{array}{c}\text { Moulouya } \\
\mathrm{N}=12\end{array}$ & $\begin{array}{c}\text { Tensift } \\
\mathbf{N}=11\end{array}$ \\
\hline \multirow{9}{*}{$\begin{array}{l}\text { SL/HL } \\
\left(H=72.86^{*}\right)\end{array}$} & Ziz & 4.1 & & & & & & & & \\
\hline & Dades & 0.57 & 4.1 & & & & & & & \\
\hline & Lakhdar & 0.08 & $0.002^{*}$ & 4.2 & & & & & & \\
\hline & Melloul & 0.16 & 0.02 & 0.92 & 4.2 & & & & & \\
\hline & Miaami & $0.001^{*}$ & $0.001^{*}$ & $0.001^{*}$ & $0.001^{*}$ & 3.8 & & & & \\
\hline & Isli & 0.02 & $0.002^{*}$ & 0.87 & 0.75 & $0.001^{*}$ & 4.3 & & & \\
\hline & Ifni & $0.001^{*}$ & $0.001^{*}$ & $0.001^{*}$ & $0.001^{*}$ & 0.31 & $0.001^{*}$ & 3.8 & & \\
\hline & Mouloya & 0.42 & 0.03 & 0.417 & 0.282 & $0.001^{*}$ & 0.393 & $0.001^{*}$ & 4.2 & \\
\hline & Tensift & 0.65 & 0.713 & $0.019^{\star}$ & 0.07 & $0.001^{*}$ & 0.022 & $0.001^{*}$ & 0.132 & 4.1 \\
\hline \multirow{9}{*}{$\begin{array}{l}S L / M L \\
(H=109.9)\end{array}$} & Ziz & 13.8 & & & & & & & & \\
\hline & Dades & 0.29 & 12.9 & & & & & & & \\
\hline & Lakhdar & 0.2 & 0.01 & 12.1 & & & & & & \\
\hline & Melloul & $0.002^{*}$ & $0.001^{*}$ & 0.38 & 11.9 & & & & & \\
\hline & Miaami & $0.001^{*}$ & $0.001^{*}$ & $0.001^{*}$ & $0.001^{*}$ & 8.9 & & & & \\
\hline & Isli & $0.001^{*}$ & $0.001^{*}$ & $0.001^{*}$ & $0.001^{*}$ & $0.001^{*}$ & 10.3 & & & \\
\hline & Ifni & $0.001^{*}$ & $0.001^{*}$ & $0.001^{*}$ & $0.001^{*}$ & $0.004^{*}$ & $0.001^{*}$ & 8.6 & & \\
\hline & Mouloya & $0.003^{*}$ & $0.001^{*}$ & 0.135 & 0.503 & $0.001^{*}$ & $0.001^{*}$ & $0.001^{*}$ & 11.6 & \\
\hline & Tensift & $0.001^{*}$ & $0.001^{*}$ & $0.025^{\star}$ & 0.064 & $0.001^{*}$ & $0.001^{*}$ & $0.001^{*}$ & 0.479 & 11.4 \\
\hline \multirow{9}{*}{$\begin{array}{l}\text { SL/UJL } \\
(H=91.24)\end{array}$} & Ziz & 8.5 & & & & & & & & \\
\hline & Dades & 0.18 & 8.3 & & & & & & & \\
\hline & Lakhdar & $0.002^{*}$ & $0.001^{*}$ & 9 & & & & & & \\
\hline & Melloul & 0.02 & $0.001^{*}$ & 0.40 & 8.9 & & & & & \\
\hline & Miaami & $0.001^{*}$ & $0.001^{*}$ & $0.001^{*}$ & $0.001^{*}$ & 7.4 & & & & \\
\hline & Isli & 0.72 & 0.68 & $0.004^{*}$ & 0.02 & $0.001^{*}$ & 8.4 & & & \\
\hline & Ifni & $0.001^{*}$ & $0.001^{*}$ & $0.001^{*}$ & $0.001^{*}$ & 1 & $0.001^{*}$ & 7.5 & & \\
\hline & Mouloya & 0.114 & $0.001^{*}$ & 0.074 & 0.361 & $0.001^{*}$ & 0.164 & $0.001^{*}$ & 8.7 & \\
\hline & Tensift & 0.967 & 0.418 & $0.003^{*}$ & $0.018^{*}$ & $0.001^{*}$ & 0.716 & $0.001^{*}$ & 0.07 & 8.5 \\
\hline \multirow{9}{*}{$\begin{array}{l}\text { SL/UJD } \\
\left(H=71.43^{*}\right)\end{array}$} & Ziz & 33.4 & & & & & & & & \\
\hline & Dades & $0.002^{*}$ & 37.2 & & & & & & & \\
\hline & Lakhdar & 0.25 & $0.002^{*}$ & 34.2 & & & & & & \\
\hline & Melloul & 0.04 & 0.23 & 0.21 & 36.2 & & & & & \\
\hline & Miaami & $0.001^{*}$ & $0.001^{*}$ & $0.001^{*}$ & $0.001^{*}$ & 26.7 & & & & \\
\hline & Isli & $0.004^{*}$ & 0.21 & 0.14 & 0.89 & $0.001^{*}$ & 36.3 & & & \\
\hline & Ifni & 0.02 & 0.87 & 0.06 & 0.61 & $0.001^{*}$ & 0.71 & 37.1 & & \\
\hline & Mouloya & 0.004 & 0.07 & $0.003^{*}$ & 0.065 & $0.001^{*}$ & $0.043^{\star}$ & 0.106 & 40.1 & \\
\hline & Tensift & $0.001^{*}$ & $0.001^{*}$ & $0.001^{*}$ & $0.001^{*}$ & $0.001^{*}$ & $0.001^{*}$ & $0.001^{*}$ & 0.148 & 42.9 \\
\hline \multirow{9}{*}{$\begin{array}{l}\text { SL/PrDD } \\
\left(H=71.15^{*}\right)\end{array}$} & Ziz & 2.2 & & & & & & & & \\
\hline & Dades & $0.001^{*}$ & 2.1 & & & & & & & \\
\hline & Lakhdar & 0.94 & $0.001^{*}$ & 2.3 & & & & & & \\
\hline & Melloul & 0.44 & $0.005^{\star}$ & 0.38 & 2.2 & & & & & \\
\hline & Miaami & 0.50 & $0.001^{*}$ & 0.10 & 0.78 & 2.2 & & & & \\
\hline & Isli & 0.10 & $0.001^{*}$ & 0.06 & 0.03 & 0.01 & 2.3 & & & \\
\hline & Ifni & $0.001^{*}$ & 0.13 & $0.001^{*}$ & $0.002^{*}$ & $0.001^{*}$ & $0.001^{*}$ & 2.1 & & \\
\hline & Mouloya & $0.034^{*}$ & $0.001^{*}$ & $0.01^{*}$ & $0.01^{*}$ & $0.001^{*}$ & 0.864 & $0.001^{*}$ & 2.3 & \\
\hline & Tensift & 0.901 & $0.001^{*}$ & 0.985 & 0.464 & 0.406 & 0.12 & $0.001^{*}$ & 0.06 & 2.2 \\
\hline \multirow{5}{*}{$\begin{array}{l}\text { SL/PrPD } \\
\left(\mathrm{H}=84.24^{*}\right)\end{array}$} & Ziz & 4.2 & & & & & & & & \\
\hline & Dades & 0.06 & 4.1 & & & & & & & \\
\hline & Lakhdar & 0.02 & $0.001^{*}$ & 4.3 & & & & & & \\
\hline & Melloul & 0.05 & $0.001^{*}$ & 0.20 & 4.4 & & & & & \\
\hline & Miaami & 0.16 & $0.006^{*}$ & 0.02 & $0.007^{*}$ & 4.2 & & & & \\
\hline
\end{tabular}


Appendix 1.- (Continued)

\begin{tabular}{|c|c|c|c|c|c|c|c|c|c|c|}
\hline $\begin{array}{l}\text { Variables } \\
\text { (H statistic) }\end{array}$ & Populations & $\begin{array}{c}\mathrm{Ziz} \\
\mathrm{N}=8\end{array}$ & $\begin{array}{c}\text { Dades } \\
\mathrm{N}=23\end{array}$ & $\begin{array}{c}\text { Lahkdar } \\
\mathbf{N}=22\end{array}$ & $\begin{array}{c}\text { Melloul } \\
\mathbf{N}=20\end{array}$ & $\begin{array}{c}\text { Miaami } \\
\mathrm{N}=14\end{array}$ & $\begin{array}{c}\text { Isli } \\
\mathrm{N}=15\end{array}$ & $\begin{array}{c}\text { Ifni } \\
\mathrm{N}=17\end{array}$ & $\begin{array}{c}\text { Moulouya } \\
\mathrm{N}=12\end{array}$ & $\begin{array}{c}\text { Tensift } \\
\mathrm{N}=11\end{array}$ \\
\hline \multirow{13}{*}{$\begin{array}{l}\text { SL/PrVD } \\
\left(H=33.15^{*}\right)\end{array}$} & Isli & $0.001^{*}$ & $0.001^{*}$ & $0.001^{*}$ & $0.002^{*}$ & $0.001^{*}$ & 4.7 & & & \\
\hline & Ifni & $0.001^{*}$ & $0.001^{*}$ & $0.001^{*}$ & $0.001^{*}$ & $0.001^{*}$ & $0.001^{*}$ & 3.9 & & \\
\hline & Mouloya & 0.6 & $0.001^{*}$ & 0.652 & 0.503 & $0.048^{*}$ & $0.001^{*}$ & $0.001^{*}$ & 4.3 & \\
\hline & Tensift & 0.901 & 0.303 & $0.001^{*}$ & $0.028^{*}$ & 0.755 & $0.001^{*}$ & $0.008^{*}$ & 0.103 & 4.1 \\
\hline & Ziz & 1.9 & & & & & & & & \\
\hline & Dades & 0.09 & 1.8 & & & & & & & \\
\hline & Lakhdar & 0.12 & $0.001^{*}$ & 1.9 & & & & & & \\
\hline & Melloul & 0.28 & 0.90 & $0.004^{*}$ & 1.8 & & & & & \\
\hline & Miaami & 0.63 & $0.001^{*}$ & 0.25 & 0.03 & 1.9 & & & & \\
\hline & Isli & 0.05 & $0.001^{*}$ & 0.33 & $0.002^{*}$ & 0.06 & 1.9 & & & \\
\hline & Ifni & 0.31 & 0.51 & $0.002^{*}$ & 0.8 & 0.02 & $0.002^{*}$ & 1.8 & & \\
\hline & Mouloya & 0.418 & 0.931 & $0.022^{*}$ & 0.7 & 0.213 & 0.014 & 0.912 & 1.8 & \\
\hline & Tensift & 0.342 & 0.31 & $0.025^{*}$ & 0.491 & 0.146 & 0.017 & 0.742 & 0.829 & 1.9 \\
\hline \multirow{9}{*}{$\begin{array}{l}\text { SL/PrAD } \\
\left(H=28.69^{*}\right)\end{array}$} & Ziz & 1.4 & & & & & & & & \\
\hline & Dades & 0.51 & 1.4 & & & & & & & \\
\hline & Lakhdar & $0.006^{*}$ & $0.001^{*}$ & 1.4 & & & & & & \\
\hline & Melloul & 0.3 & 0.13 & $0.004^{*}$ & 1.4 & & & & & \\
\hline & Miaami & 0.03 & $0.009^{*}$ & 0.67 & 0.02 & 1.4 & & & & \\
\hline & Isli & 0.04 & 0.02 & 0.49 & 0.01 & 0.62 & 1.4 & & & \\
\hline & Ifni & 0.12 & 0.20 & 0.10 & 0.04 & 0.26 & 0.15 & 1.4 & & \\
\hline & Mouloya & 0.847 & 0.986 & 0.015 & 0.341 & $0.043^{*}$ & 0.06 & 0.298 & 1.4 & \\
\hline & Tensift & $0.015^{\star}$ & $0.003^{*}$ & 0.775 & $0.022^{*}$ & 1 & 0.64 & 0.1 & $0.034^{*}$ & 1.4 \\
\hline \multirow{9}{*}{$\begin{array}{l}\text { SL/CPL } \\
\left(H=99.07^{*}\right)\end{array}$} & Ziz & 2.4 & & & & & & & & \\
\hline & Dades & 0.09 & 2.4 & & & & & & & \\
\hline & Lakhdar & $0.003^{*}$ & $0.001^{*}$ & 2.3 & & & & & & \\
\hline & Melloul & $0.001^{*}$ & $0.001^{*}$ & $0.001^{*}$ & 2.2 & & & & & \\
\hline & Miaami & $0.001^{*}$ & $0.001^{*}$ & $0.001^{*}$ & 0.47 & 2.2 & & & & \\
\hline & Isli & $0.006^{*}$ & $0.001^{*}$ & 0.17 & 0.30 & 0.48 & 2.2 & & & \\
\hline & Ifni & $0.001^{*}$ & $0.002^{*}$ & $0.001^{*}$ & $0.001^{*}$ & $0.001^{*}$ & $0.001^{*}$ & 2.5 & & \\
\hline & Mouloya & $0.001^{*}$ & $0.001^{*}$ & $0.035^{*}$ & 0.231 & 0.393 & 0.788 & $0.001^{*}$ & 2.2 & \\
\hline & Tensift & $0.023^{\star}$ & $0.001^{*}$ & 0.113 & $0.001^{*}$ & $0.001^{*}$ & 0.069 & $0.001^{*}$ & $0.001^{*}$ & 2.3 \\
\hline \multirow{9}{*}{$\begin{array}{l}\text { SL/CPA } \\
\left(H=117.6^{*}\right)\end{array}$} & Ziz & 5.5 & & & & & & & & \\
\hline & Dades & 0.17 & 5.6 & & & & & & & \\
\hline & Lakhdar & 0.44 & $0.003^{*}$ & 5.4 & & & & & & \\
\hline & Melloul & $0.001^{*}$ & $0.001^{*}$ & $0.001^{*}$ & 4.7 & & & & & \\
\hline & Miaami & $0.001^{*}$ & $0.001^{*}$ & $0.001^{*}$ & $0.001^{*}$ & 4.3 & & & & \\
\hline & Isli & $0.001^{*}$ & $0.001^{*}$ & $0.001^{*}$ & 0.04 & 0.01 & 4.5 & & & \\
\hline & Ifni & $0.001^{*}$ & $0.001^{*}$ & $0.001^{*}$ & 0.04 & $0.001^{*}$ & $0.001^{*}$ & 4.9 & & \\
\hline & Mouloya & 0.07 & $0.001^{*}$ & 0.074 & $0.001^{*}$ & $0.001^{*}$ & $0.001^{*}$ & $0.001^{*}$ & 5.3 & \\
\hline & Tensift & 0.231 & 0.581 & $0.041^{*}$ & $0.001^{*}$ & $0.001^{*}$ & $0.001^{*}$ & $0.001^{*}$ & $0.005^{*}$ & 5.6 \\
\hline \multirow{9}{*}{$\begin{array}{l}\text { SL/APL } \\
\left(H=84.47^{*}\right)\end{array}$} & Ziz & 4.9 & & & & & & & & \\
\hline & Dades & 0.67 & 4.9 & & & & & & & \\
\hline & Lakhdar & 0.02 & $0.001^{*}$ & 4.7 & & & & & & \\
\hline & Melloul & 0.17 & 0.12 & $0.001^{*}$ & 5.1 & & & & & \\
\hline & Miaami & 0.72 & 0.35 & $0.009^{*}$ & 0.06 & 4.9 & & & & \\
\hline & Isli & $0.001^{*}$ & $0.001^{*}$ & $0.001^{*}$ & 0.05 & $0.001^{*}$ & 5.4 & & & \\
\hline & Ifni & $0.001^{*}$ & $0.001^{*}$ & $0.001^{*}$ & $0.001^{*}$ & $0.001^{*}$ & 0.04 & 5.7 & & \\
\hline & Mouloya & 0.005 & $0.001^{*}$ & 0.165 & $0.001^{*}$ & $0.002^{*}$ & $0.001^{*}$ & $0.001^{*}$ & 4.6 & \\
\hline & Tensift & 0.035 & $0.007^{\star}$ & 0.924 & $0.004^{\star}$ & 0.055 & $0.001^{*}$ & $0.001^{*}$ & 0.31 & 4.7 \\
\hline
\end{tabular}


Appendix 1.- (Continued)

\begin{tabular}{|c|c|c|c|c|c|c|c|c|c|c|}
\hline $\begin{array}{l}\text { Variables } \\
\text { (H statistic) }\end{array}$ & Populations & $\begin{array}{c}Z i z \\
\mathrm{~N}=8\end{array}$ & $\begin{array}{c}\text { Dades } \\
\mathbf{N}=23\end{array}$ & $\begin{array}{c}\text { Lahkdar } \\
\mathrm{N}=22\end{array}$ & $\begin{array}{c}\text { Melloul } \\
\mathbf{N}=\mathbf{2 0}\end{array}$ & $\begin{array}{c}\text { Miaami } \\
\mathrm{N}=14\end{array}$ & $\begin{array}{c}\text { Isli } \\
\mathrm{N}=15\end{array}$ & $\begin{array}{c}\text { Ifni } \\
\mathrm{N}=17\end{array}$ & $\begin{array}{c}\text { Moulouya } \\
\mathrm{N}=12\end{array}$ & $\begin{array}{c}\text { Tensift } \\
\mathrm{N}=11\end{array}$ \\
\hline \multirow{9}{*}{$\begin{array}{l}\text { SL/PFL } \\
\left(H=82.09^{*}\right)\end{array}$} & Ziz & 4.5 & & & & & & & & \\
\hline & Dades & 0.01 & 4.8 & & & & & & & \\
\hline & Lakhdar & 0.02 & 0.14 & 4.9 & & & & & & \\
\hline & Melloul & 0.02 & 0.06 & 0.38 & 4.9 & & & & & \\
\hline & Miaami & 0.18 & $0.001^{*}$ & $0.001^{*}$ & $0.001^{*}$ & 4.2 & & & & \\
\hline & Isli & $0.001^{*}$ & $0.001^{*}$ & $0.001^{*}$ & $0.001^{*}$ & $0.001^{*}$ & 5.7 & & & \\
\hline & Ifni & 0.04 & $0.007^{*}$ & 0.01 & $0.01^{*}$ & $0.001^{*}$ & $0.001^{*}$ & 4.7 & & \\
\hline & Mouloya & $0.01^{*}$ & 0.046 & 0.397 & 0.792 & $0.001^{*}$ & $0.001^{*}$ & $0.011^{*}$ & 5 & \\
\hline & Tensift & $0.012^{*}$ & $0.001^{*}$ & 0.294 & 0.966 & $0.001^{*}$ & $0.001^{*}$ & $0.001^{*}$ & 0.878 & 4.7 \\
\hline \multirow{9}{*}{$\begin{array}{l}\text { SL/DFL } \\
(H=93.38)\end{array}$} & Ziz & 6.4 & & & & & & & & \\
\hline & Dades & $0.001^{*}$ & 7.3 & & & & & & & \\
\hline & Lakhdar & $0.001^{*}$ & 0.06 & 7.1 & & & & & & \\
\hline & Melloul & $0.001^{*}$ & 0.17 & 0.01 & 7.8 & & & & & \\
\hline & Miaami & 0.72 & $0.001^{*}$ & $0.001^{*}$ & $0.001^{*}$ & 6.4 & & & & \\
\hline & Isli & $0.001^{*}$ & 0.70 & 0.18 & 0.20 & $0.001^{*}$ & 7.3 & & & \\
\hline & Ifni & $0.001^{*}$ & $0.002^{*}$ & 0.79 & $0.003^{*}$ & $0.001^{*}$ & 0.07 & 7 & & \\
\hline & Mouloya & 0.969 & $0.001^{*}$ & $0.001^{*}$ & $0.001^{*}$ & 0.714 & $0.001^{*}$ & $0.001^{*}$ & 6.4 & \\
\hline & Tensift & $0.011^{*}$ & $0.001^{*}$ & $0.001^{*}$ & $0.001^{*}$ & $0.003^{*}$ & $0.001^{*}$ & $0.001^{*}$ & $0.045^{\star}$ & 6.1 \\
\hline \multirow{9}{*}{$\begin{array}{l}\text { SL/DFH } \\
\left(H=90.23^{*}\right)\end{array}$} & Ziz & 4.8 & & & & & & & & \\
\hline & Dades & $0.002^{*}$ & 5.4 & & & & & & & \\
\hline & Lakhdar & $0.001^{*}$ & 0.23 & 5.5 & & & & & & \\
\hline & Melloul & $0.001^{*}$ & 0.43 & 0.82 & 5.5 & & & & & \\
\hline & Miaami & 0.97 & $0.001^{*}$ & $0.001^{*}$ & $0.001^{*}$ & 4.7 & & & & \\
\hline & Isli & $0.001^{*}$ & $0.001^{*}$ & $0.001^{*}$ & $0.001^{*}$ & $0.001^{*}$ & 5.8 & & & \\
\hline & Ifni & 0.47 & $0.001^{*}$ & $0.001^{*}$ & $0.001^{*}$ & 0.29 & $0.001^{*}$ & 4.8 & & \\
\hline & Mouloya & $0.004^{*}$ & 0.875 & 0.438 & 0.761 & $0.001^{*}$ & $0.001^{*}$ & $0.001^{*}$ & 5.4 & \\
\hline & Tensift & $0.007^{*}$ & $0.001^{*}$ & $0.001^{*}$ & 0.071 & $0.001^{*}$ & $0.001^{*}$ & $0.001^{*}$ & 0.052 & 5.2 \\
\hline \multirow{9}{*}{$\begin{array}{l}\text { SL/VFL } \\
\left(H=93.07^{*}\right)\end{array}$} & Ziz & 6 & & & & & & & & \\
\hline & Dades & 0.01 & 6.5 & & & & & & & \\
\hline & Lakhdar & $0.001^{*}$ & 0.02 & 6.7 & & & & & & \\
\hline & Melloul & $0.001^{*}$ & $0.001^{*}$ & 0.03 & 7 & & & & & \\
\hline & Miaami & 0.46 & $0.001^{*}$ & $0.001^{*}$ & $0.001^{*}$ & 5.7 & & & & \\
\hline & Isli & $0.001^{*}$ & $0.001^{*}$ & $0.001^{*}$ & $0.001^{*}$ & $0.001^{*}$ & 7.6 & & & \\
\hline & Ifni & 0.05 & 0.58 & $0.006^{*}$ & $0.001^{*}$ & $0.001^{*}$ & $0.001^{*}$ & 6.3 & & \\
\hline & Mouloya & $0.001^{*}$ & $0.002^{*}$ & 0.417 & 0.085 & $0.001^{*}$ & $0.001^{*}$ & 0.001 & 6.8 & \\
\hline & Tensift & $0.001^{*}$ & $0.001^{*}$ & 0.35 & 0.064 & $0.001^{*}$ & $0.001^{*}$ & $0.001^{*}$ & 0.479 & 6.8 \\
\hline \multirow{9}{*}{$\begin{array}{l}\text { SL/AFL } \\
\left(H=63.95^{*}\right)\end{array}$} & Ziz & 9.9 & & & & & & & & \\
\hline & Dades & 0.02 & 10.3 & & & & & & & \\
\hline & Lakhdar & 0.09 & 0.27 & 10.2 & & & & & & \\
\hline & Melloul & 0.25 & 0.31 & 0.89 & 10.1 & & & & & \\
\hline & Miaami & $0.001^{*}$ & $0.001^{*}$ & $0.001^{*}$ & $0.001^{*}$ & 9.1 & & & & \\
\hline & Isli & 0.23 & $0.001^{*}$ & 0.01 & 0.03 & $0.007^{\star}$ & 9.6 & & & \\
\hline & Ifni & 0.07 & $0.001^{*}$ & $0.005^{\star}$ & $0.004^{*}$ & $0.004^{*}$ & 0.97 & 9.5 & & \\
\hline & Mouloya & 0.298 & 0.035 & 0.288 & 0.401 & $0.001^{*}$ & 0.067 & 0.04 & 10 & \\
\hline & Tensift & $0.001^{*}$ & $0.001^{*}$ & $0.001^{*}$ & $0.001^{*}$ & 0.568 & $0.003^{*}$ & 0.003 & $0.001^{*}$ & 9 \\
\hline \multirow{4}{*}{$\begin{array}{l}\text { SL/AFH } \\
\left(H=91.24^{*}\right)\end{array}$} & Ziz & 5.5 & & & & & & & & \\
\hline & Dades & $0.001^{*}$ & 6.1 & & & & & & & \\
\hline & Lakhdar & $0.001^{*}$ & 0.20 & 6.1 & & & & & & \\
\hline & Melloul & $0.001^{*}$ & 0.10 & 0.38 & 6.3 & & & & & \\
\hline
\end{tabular}


Appendix 1.- (Continued)

\begin{tabular}{|c|c|c|c|c|c|c|c|c|c|c|}
\hline $\begin{array}{l}\text { Variables } \\
\text { (H statistic) }\end{array}$ & Populations & $\begin{array}{c}\mathrm{Ziz} \\
\mathrm{N}=8\end{array}$ & $\begin{array}{l}\text { Dades } \\
\mathrm{N}=23\end{array}$ & $\begin{array}{c}\text { Lahkdar } \\
\mathbf{N}=22\end{array}$ & $\begin{array}{c}\text { Melloul } \\
\mathbf{N}=20\end{array}$ & $\begin{array}{c}\text { Miaami } \\
\mathrm{N}=14\end{array}$ & $\begin{array}{c}\text { Isli } \\
N=15\end{array}$ & $\begin{array}{c}\text { Ifni } \\
N=17\end{array}$ & $\begin{array}{c}\text { Moulouya } \\
\mathrm{N}=12\end{array}$ & $\begin{array}{c}\text { Tensift } \\
\mathrm{N}=11\end{array}$ \\
\hline \multirow{14}{*}{$\begin{array}{l}\text { SL/CFL } \\
\left(H=84.22^{*}\right)\end{array}$} & Miaami & 0.15 & $0.001^{*}$ & $0.001^{*}$ & $0.001^{*}$ & 5.3 & & & & \\
\hline & Isli & $0.001^{*}$ & $0.001^{*}$ & $0.001^{*}$ & $0.006^{*}$ & $0.001^{*}$ & 6.7 & & & \\
\hline & Ifni & 0.93 & $0.001^{*}$ & $0.001^{*}$ & $0.001^{*}$ & 0.02 & $0.001^{*}$ & 5.5 & & \\
\hline & Mouloya & $0.002^{*}$ & 0.986 & 0.322 & 0.429 & $0.001^{*}$ & $0.001^{*}$ & $0.001^{*}$ & 6.1 & \\
\hline & Tensift & $0.001^{*}$ & 0.269 & 0.985 & 0.464 & $0.001^{*}$ & $0.001^{*}$ & $0.001^{*}$ & 0.479 & 6.1 \\
\hline & Ziz & 5.5 & & & & & & & & \\
\hline & Dades & 0.23 & 5.6 & & & & & & & \\
\hline & Lakhdar & $0.008^{*}$ & $0.001^{*}$ & 5.9 & & & & & & \\
\hline & Melloul & $0.001^{*}$ & $0.001^{*}$ & $0.005^{*}$ & 6.3 & & & & & \\
\hline & Miaami & 0.5 & 0.02 & $0.001^{*}$ & $0.001^{*}$ & 5.3 & & & & \\
\hline & Isli & $0.001^{*}$ & $0.001^{*}$ & 0.02 & 0.89 & $0.001^{*}$ & 6.2 & & & \\
\hline & Ifni & $0.005^{\star}$ & $0.001^{*}$ & $0.01^{*}$ & $0.001^{*}$ & $0.007^{*}$ & $0.001^{*}$ & 5 & & \\
\hline & Mouloya & 0.153 & 0.205 & 0.155 & $0.005^{\star}$ & $0.007^{\star}$ & $0.014^{\star}$ & $0.001^{*}$ & 5.7 & \\
\hline & Tensift & $0.019^{\star}$ & $0.001^{*}$ & 0.688 & $0.064^{*}$ & $0.001^{*}$ & 0.087 & $0.001^{*}$ & 0.148 & 5.9 \\
\hline \multirow{9}{*}{$\begin{array}{l}\text { SL/BLD } \\
\left(H=75.63^{*}\right)\end{array}$} & Ziz & 8.9 & & & & & & & & \\
\hline & Dades & $0.001^{*}$ & 9.4 & & & & & & & \\
\hline & Lakhdar & $0.001^{*}$ & 0.02 & 9.6 & & & & & & \\
\hline & Melloul & 0.08 & $0.001^{*}$ & $0.001^{*}$ & 9.1 & & & & & \\
\hline & Miaami & 0.2 & $0.001^{*}$ & $0.001^{*}$ & $0.001^{*}$ & 8.6 & & & & \\
\hline & Isli & $0.001^{*}$ & $0.001^{*}$ & $0.001^{*}$ & $0.001^{*}$ & $0.001^{*}$ & 10.4 & & & \\
\hline & Ifni & 0.03 & $0.001^{*}$ & $0.001^{*}$ & $0.001^{*}$ & 0.43 & $0.001^{*}$ & 8.6 & & \\
\hline & Mouloya & $0.002^{*}$ & $0.001^{*}$ & $0.001^{*}$ & $0.001^{*}$ & 0.113 & $0.001^{*}$ & $0.001^{*}$ & 9.2 & \\
\hline & Tensift & $0.002^{*}$ & $0.001^{*}$ & $0.001^{*}$ & $0.001^{*}$ & 0.377 & $0.001^{*}$ & $0.001^{*}$ & $0.029^{*}$ & 9 \\
\hline \multirow{9}{*}{$\begin{array}{l}\text { SL/BA } \\
\left(H=79.74^{*}\right)\end{array}$} & Ziz & 5.4 & & & & & & & & \\
\hline & Dades & $0.001^{*}$ & 5.9 & & & & & & & \\
\hline & Lakhdar & 0.02 & $0.005^{\star}$ & 5.7 & & & & & & \\
\hline & Melloul & 0.17 & $0.001^{*}$ & $0.001^{*}$ & 5.3 & & & & & \\
\hline & Miaami & $0.001^{*}$ & $0.001^{*}$ & $0.001^{*}$ & $0.001^{*}$ & 4.8 & & & & \\
\hline & Isli & 0.92 & $0.001^{*}$ & 0.04 & 0.27 & $0.001^{*}$ & 5.4 & & & \\
\hline & Ifni & 0.37 & $0.001^{*}$ & $0.001^{*}$ & 0.41 & $0.001^{*}$ & 0.57 & 5.4 & & \\
\hline & Mouloya & 0.07 & $0.001^{*}$ & $0.001^{*}$ & 0.7 & $0.001^{*}$ & 0.196 & 0.191 & 5.2 & \\
\hline & Tensift & 0.052 & $0.001^{*}$ & $0.001^{*}$ & 0.9 & $0.001^{*}$ & 0.35 & 0.188 & 0.829 & 5.3 \\
\hline \multirow{9}{*}{$\begin{array}{l}\text { SL/BD } \\
\left(H=75.63^{*}\right)\end{array}$} & Ziz & 4 & & & & & & & & \\
\hline & Dades & $0.005^{\star}$ & 4.2 & & & & & & & \\
\hline & Lakhdar & 0.06 & 0.06 & 4.1 & & & & & & \\
\hline & Melloul & 0.35 & $0.001^{*}$ & $0.005^{\star}$ & 3.9 & & & & & \\
\hline & Miaami & 0.02 & $0.001^{*}$ & $0.001^{*}$ & 0.01 & 3.7 & & & & \\
\hline & Isli & 0.97 & $0.001^{*}$ & 0.03 & 0.35 & $0.003^{*}$ & 3.9 & & & \\
\hline & Ifni & 0.25 & 0.07 & 0.62 & 0.02 & $0.001^{*}$ & 0.16 & 4.1 & & \\
\hline & Mouloya & $0.002^{*}$ & $0.001^{*}$ & $0.001^{*}$ & $0.001^{*}$ & 0.113 & $0.001^{*}$ & $0.001^{*}$ & 3.6 & \\
\hline & Tensift & $0.002^{*}$ & $0.001^{*}$ & $0.001^{*}$ & $0.001^{*}$ & 0.377 & $0.001^{*}$ & $0.001^{*}$ & $0.029^{*}$ & 3.7 \\
\hline \multirow{9}{*}{$\begin{array}{l}\text { HL/UJL } \\
\left(\begin{array}{l}\left(H=43.73^{*}\right)\end{array}\right.\end{array}$} & Ziz & 3.2 & & & & & & & & \\
\hline & Dades & 0.73 & 3.1 & & & & & & & \\
\hline & Lakhdar & 0.08 & 0.01 & 2.9 & & & & & & \\
\hline & Melloul & 0.23 & 0.05 & 0.57 & 2.8 & & & & & \\
\hline & Miaami & $0.002^{*}$ & $0.001^{*}$ & $0.001^{*}$ & $0.001^{*}$ & 2.4 & & & & \\
\hline & Isli & 0.04 & 0.03 & $0.001^{*}$ & $0.007^{\star}$ & 0.08 & 2.4 & & & \\
\hline & Ifni & 0.06 & 0.02 & $0.001^{*}$ & $0.003^{*}$ & 0.52 & 0.54 & 2.2 & & \\
\hline & Mouloya & 0.263 & $0.049^{*}$ & 0.377 & 0.855 & $0.001^{*}$ & $0.005^{\star}$ & $0.007^{*}$ & 2.1 & \\
\hline & Tensift & 0.901 & 0.357 & 0.175 & 0.389 & $0.001^{*}$ & $0.013^{*}$ & $0.016^{\star}$ & 0.518 & 2.1 \\
\hline
\end{tabular}


Appendix 1.- (Continued)

\begin{tabular}{|c|c|c|c|c|c|c|c|c|c|c|}
\hline $\begin{array}{l}\text { Variables } \\
\text { (H statistic) }\end{array}$ & Populations & $\begin{array}{c}Z i z \\
N=8\end{array}$ & $\begin{array}{c}\text { Dades } \\
\mathrm{N}=23\end{array}$ & $\begin{array}{c}\text { Lahkdar } \\
\mathrm{N}=22\end{array}$ & $\begin{array}{c}\text { Melloul } \\
\mathbf{N}=\mathbf{2 0}\end{array}$ & $\begin{array}{c}\text { Miaami } \\
N=14\end{array}$ & $\begin{array}{c}\text { Isli } \\
\mathrm{N}=15\end{array}$ & $\begin{array}{c}\text { Ifni } \\
\mathrm{N}=17\end{array}$ & $\begin{array}{c}\text { Moulouya } \\
\mathrm{N}=12\end{array}$ & $\begin{array}{r}\text { Tensif } \\
\mathrm{N}=11\end{array}$ \\
\hline \multirow{9}{*}{$\begin{array}{l}\text { HL/ML } \\
\left(H=120^{*}\right)\end{array}$} & Ziz & 2.1 & & & & & & & & \\
\hline & Dades & 0.57 & 2 & & & & & & & \\
\hline & Lakhdar & $0.001^{*}$ & $0.001^{*}$ & 2.1 & & & & & & \\
\hline & Melloul & $0.001^{*}$ & $0.001^{*}$ & 0.13 & 2.1 & & & & & \\
\hline & Miaami & $0.001^{*}$ & $0.001^{*}$ & $0.001^{*}$ & $0.001^{*}$ & 2.4 & & & & \\
\hline & Isli & $0.001^{*}$ & $0.001^{*}$ & $0.001^{*}$ & $0.001^{*}$ & 0.16 & 2 & & & \\
\hline & Ifni & $0.001^{*}$ & $0.001^{*}$ & $0.001^{*}$ & $0.001^{*}$ & $0.001^{*}$ & $0.001^{*}$ & 1.9 & & \\
\hline & Mouloya & $0.001^{*}$ & $0.001^{*}$ & 0.482 & 0.984 & $0.001^{*}$ & $0.001^{*}$ & $0.001^{*}$ & 2.8 & \\
\hline & Tensift & $0.001^{*}$ & $0.001^{*}$ & 0.141 & 0.966 & $0.001^{*}$ & $0.001^{*}$ & $0.001^{*}$ & 0.878 & 2.8 \\
\hline \multirow{9}{*}{$\begin{array}{l}\text { ML/UJD } \\
\left(H=97.67^{*}\right)\end{array}$} & Ziz & 3.9 & & & & & & & & \\
\hline & Dades & $0.001^{*}$ & 4.5 & & & & & & & \\
\hline & Lakhdar & 0.62 & $0.001^{*}$ & 3.8 & & & & & & \\
\hline & Melloul & 0.54 & $0.001^{*}$ & 0.07 & 4 & & & & & \\
\hline & Miaami & $0.009^{*}$ & $0.001^{*}$ & 0.03 & $0.001^{*}$ & 3.6 & & & & \\
\hline & Isli & 0.08 & 0.28 & $0.006^{*}$ & 0.14 & $0.001^{*}$ & 4.3 & & & \\
\hline & Ifni & $0.001^{*}$ & $0.001^{*}$ & $0.001^{*}$ & $0.001^{*}$ & $0.001^{*}$ & $0.001^{*}$ & 4.9 & & \\
\hline & Mouloya & $0.001^{*}$ & $0.001^{*}$ & $0.001^{*}$ & $0.004^{*}$ & $0.002^{*}$ & 0.608 & $0.001^{*}$ & 3.5 & \\
\hline & Tensift & $0.001^{*}$ & $0.001^{*}$ & $0.001^{*}$ & $0.001^{*}$ & $0.001^{*}$ & 0.069 & $0.001^{*}$ & 0.091 & 3.8 \\
\hline \multirow{9}{*}{$\begin{array}{l}\text { CPL/CPA } \\
\left(H=105.2^{*}\right)\end{array}$} & Ziz & 2.3 & & & & & & & & \\
\hline & Dades & 0.98 & 2.3 & & & & & & & \\
\hline & Lakhdar & 0.06 & 0.01 & 2.4 & & & & & & \\
\hline & Melloul & $0.007^{*}$ & $0.001^{*}$ & $0.001^{*}$ & 2.1 & & & & & \\
\hline & Miaami & $0.001^{*}$ & $0.001^{*}$ & $0.001^{*}$ & $0.001^{*}$ & 1.9 & & & & \\
\hline & Isli & $0.001^{*}$ & $0.001^{*}$ & $0.001^{*}$ & 0.02 & 0.02 & 2 & & & \\
\hline & Ifni & $0.001^{*}$ & $0.001^{*}$ & $0.001^{*}$ & $0.001^{*}$ & 0.26 & 0.11 & 2 & & \\
\hline & Mouloya & 0.132 & $0.033^{*}$ & 0.601 & $0.001^{*}$ & $0.001^{*}$ & $0.001^{*}$ & $0.001^{*}$ & 2.4 & \\
\hline & Tensift & $0.035^{*}$ & $0.011^{*}$ & 0.33 & $0.001^{*}$ & $0.001^{*}$ & $0.001^{*}$ & $0.001^{*}$ & 0.644 & 2.4 \\
\hline \multirow{9}{*}{$\begin{array}{l}\text { APL/BLD } \\
\left(\mathrm{H}=\mathbf{8 8 . 1 1 ^ { * }}\right)\end{array}$} & Ziz & 1.8 & & & & & & & & \\
\hline & Dades & 0.02 & 2.3 & & & & & & & \\
\hline & Lakhdar & $0.001^{*}$ & $0.001^{*}$ & 2 & & & & & & \\
\hline & Melloul & 0.47 & 0.02 & $0.001^{*}$ & 1.8 & & & & & \\
\hline & Miaami & 0.42 & $0.001^{*}$ & $0.001^{*}$ & 0.86 & 1.8 & & & & \\
\hline & Isli & 0.02 & 0.65 & $0.008^{*}$ & $0.009^{*}$ & $0.001^{*}$ & 1.9 & & & \\
\hline & Ifni & $0.001^{*}$ & $0.001^{*}$ & $0.001^{*}$ & $0.001^{*}$ & $0.001^{*}$ & $0.001^{*}$ & 1.5 & & \\
\hline & Mouloya & $0.001^{*}$ & 0.009 & 0.117 & $0.001^{*}$ & $0.001^{*}$ & $0.092^{*}$ & $0.001^{*}$ & 2 & \\
\hline & Tensift & 0.043 & 0.797 & $0.005^{\star}$ & $0.014^{*}$ & $0.002^{*}$ & $0.716^{\star}$ & $0.001^{*}$ & 0.103 & 1.9 \\
\hline \multirow{9}{*}{$\begin{array}{l}\text { CPL/BA } \\
\left(H=68.42^{*}\right)\end{array}$} & Ziz & 0.98 & & & & & & & & \\
\hline & Dades & $0.004^{*}$ & 1.1 & & & & & & & \\
\hline & Lakhdar & 0.01 & 0.41 & 1 & & & & & & \\
\hline & Melloul & $0.001^{*}$ & 0.01 & $0.006^{*}$ & 1.1 & & & & & \\
\hline & Miaami & $0.001^{*}$ & 0.01 & $0.003^{*}$ & 0.7 & 1.1 & & & & \\
\hline & Isli & $0.001^{*}$ & $0.001^{*}$ & $0.001^{*}$ & 0.03 & $0.008^{*}$ & 1.2 & & & \\
\hline & Ifni & $0.001^{*}$ & 0.02 & 0.01 & 0.25 & 0.54 & $0.001^{*}$ & 1.1 & & \\
\hline & Mouloya & 0.177 & 0.114 & $0.014^{*}$ & 0.503 & $0.001^{*}$ & 0.164 & $0.001^{*}$ & 2.4 & \\
\hline & Tensift & 0.967 & $0.002^{*}$ & $0.001^{*}$ & 0.078 & $0.004^{*}$ & $0.017^{\star}$ & $0.001^{*}$ & 0.148 & 2.3 \\
\hline
\end{tabular}


Appendix 2.- Osteological Features.

Apéndice 2.- Características osteológicas.

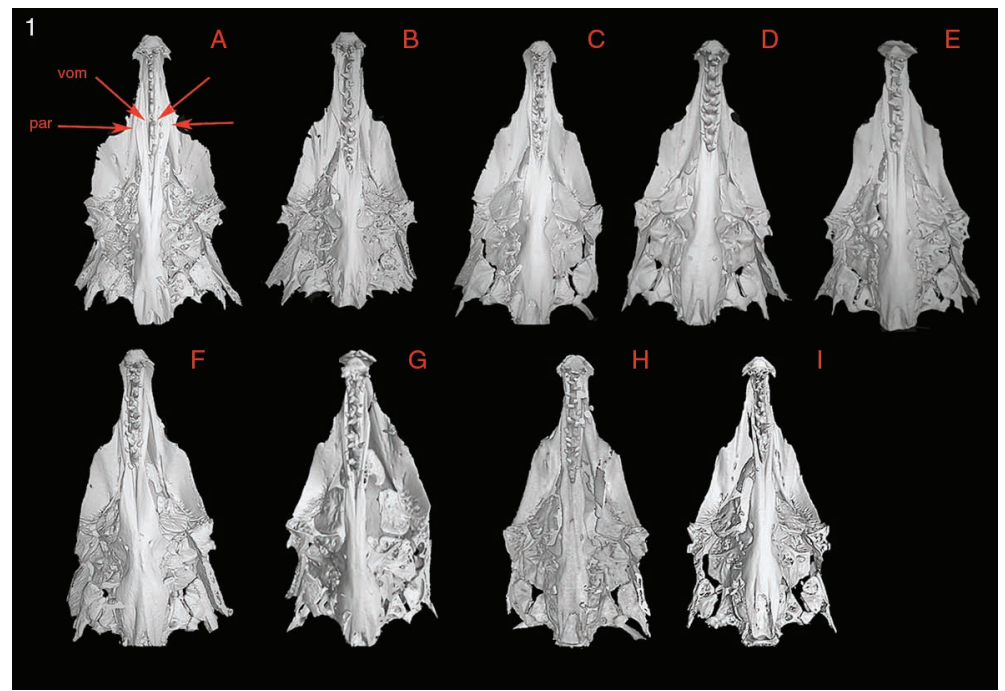

1. Ventral view of the skull showing morphology of parasphenoides (par) and vomer (vom) in Salmo populations. Isli Lake population has a single row of teeth (marked with arrows), in the other populations vomer teeth are placed in zigzag. The vomer is longer in Ifni than in the other populations. $A=I s l i, 222.6 \mathrm{~mm} \mathrm{SL}$. B=Ifni, $154.9 \mathrm{~mm} \mathrm{SL}$. C=Miaami, 77.1 mm SL. D=Ziz, $97.1 \mathrm{~mm} \mathrm{SL}$. E=Dades, $98.6 \mathrm{~mm} \mathrm{SL}$. F=Melloul, $105.2 \mathrm{~mm} \mathrm{SL}$. G=Lakhdar, $110.4 \mathrm{~mm} \mathrm{SL}$. H=Moulouya, $107.8 \mathrm{~mm} \mathrm{SL}$. I=Tensift, $111.9 \mathrm{~mm}$ SL. All individuals are mature males.

1. Vista ventral del cráneo mostrando la morfología del paraesfenoides (par) y vómer (vom) en las poblaciones de Salmo. La población del Lago Isli tiene una única fila de dientes (marcada con flechas), en las otras poblaciones los dientes del vómer están colocados en zigzag. El vómer es más largo que en las otras poblaciones. A=Isli, $222.6 \mathrm{~mm} \mathrm{SL}$. B=lfni, $154.9 \mathrm{~mm} \mathrm{SL}$. C=Miaami, $77.1 \mathrm{~mm} \mathrm{SL}$. D=Ziz, 97.1 mm SL. E=Dades, $98.6 \mathrm{~mm} \mathrm{SL}$. F=Melloul, $105.2 \mathrm{~mm} \mathrm{SL}$. G=Lakhdar, $110.4 \mathrm{~mm} \mathrm{SL}$. H=Moulouya, $107.8 \mathrm{~mm}$ SL. I=Tensift, $111.9 \mathrm{~mm}$ SL. Todos los individuos son machos maduros.

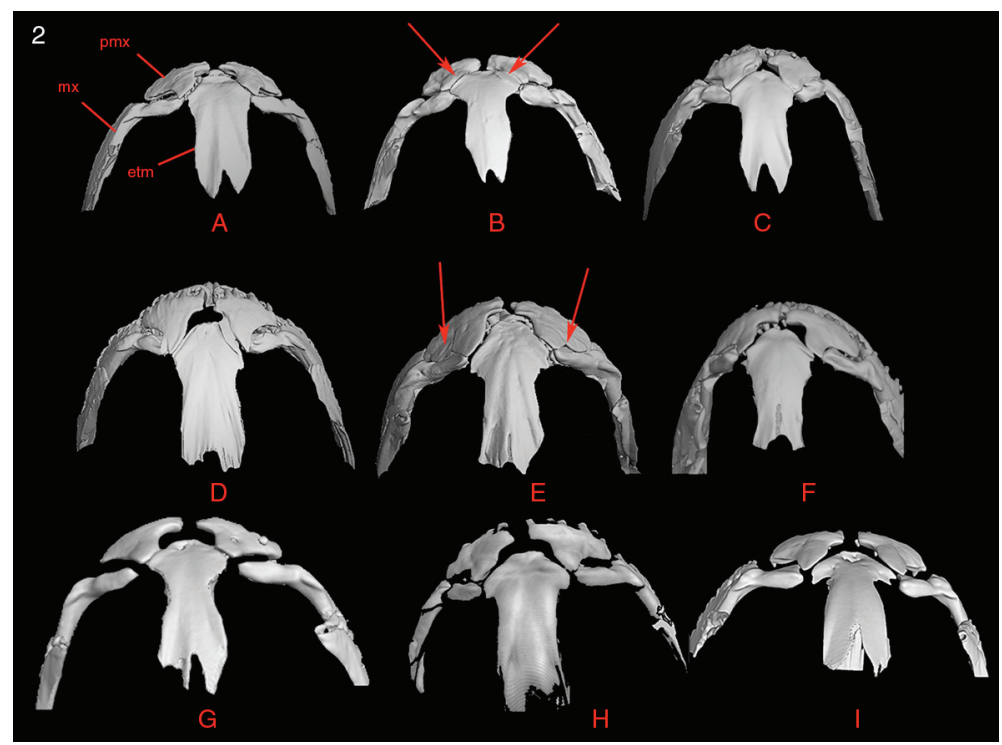

2. Joint of the ethmoid, premaxilla and maxilla bones in Atlantic Salmo populations from Morocco. Dades population shows an extended premaxilla processes. Isli population shows a robust and ossified premaxilla. A=Melloul, $105.2 \mathrm{~mm}$ SL. B=Dades, $126.4 \mathrm{~mm}$ SL. C=Ziz, 97.1 mm SL. D=Miaami, 77.1 mm SL. E=Isli, 222.6 mm SL. F=lfni, 154.9 mm SL. G=Lakhdar, 110.4 mm SL. H=Moulouya, $107.8 \mathrm{~mm} \mathrm{SL}$. I=Tensift, $111.9 \mathrm{~mm} \mathrm{SL}$. Etm=ethmoid bone. $\mathrm{Pmx}=$ premaxilla. $\mathrm{Mx}=$ maxilla. All individuals are mature males

2. Articulación del etmoides, la premaxila y la maxila en las poblaciones atlánticas de Salmo de Marruecos. La población del Dades muestra un proceso de la premaxila extendido. La población de Isli muestra una maxila robusta y osificada. A=Melloul, $105.2 \mathrm{~mm}$ SL. B=Dades, $126.4 \mathrm{~mm}$ SL. C=Ziz, $97.1 \mathrm{~mm}$ SL. D=Miaami, $77.1 \mathrm{~mm} \mathrm{SL}$. E=Isli, $222.6 \mathrm{~mm}$ SL. F=Ifni, $154.9 \mathrm{~mm} \mathrm{SL}$. $\mathrm{G}=$ Lakhdar, $110.4 \mathrm{~mm}$ SL. H=Moulouya, $107.8 \mathrm{~mm} \mathrm{SL}$. I=Tensift, $111.9 \mathrm{~mm} \mathrm{SL}$. Etm=etmoides. Pmx=premaxila. Mx=Maxilla. Todos los individuos son machos maduros. 


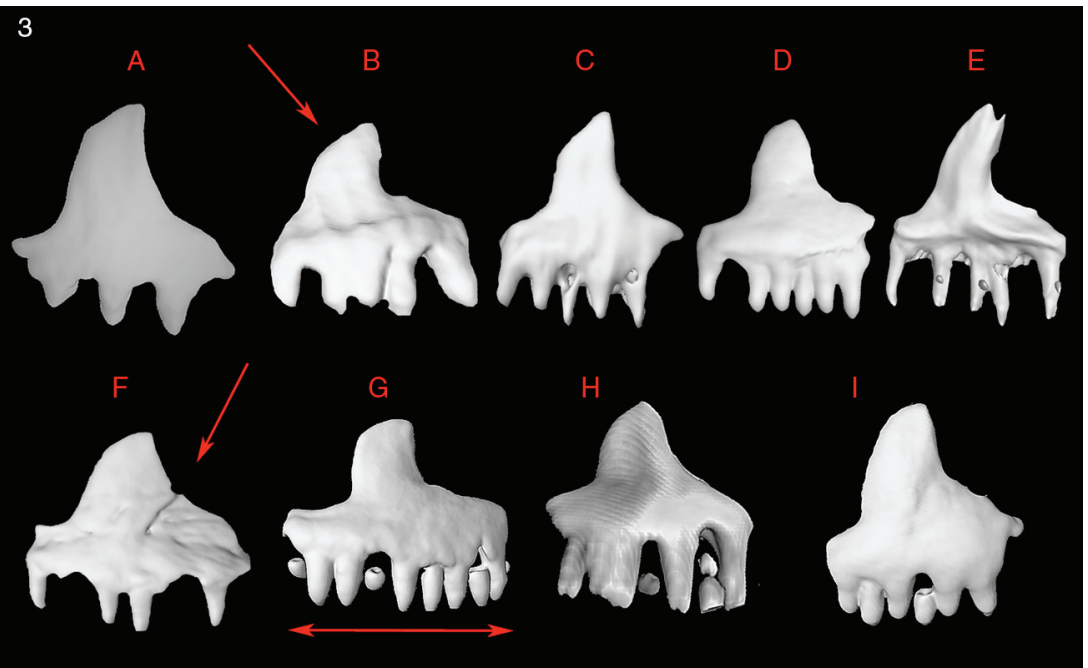

3. Premaxilla in Atlantic Salmo populations from Morocco. Dades population has a small and inclined upper process. Ifni population has the basal plate longer than the other populations. Isli population is strongly ossified. A=Melloul, $105.2 \mathrm{~mm} \mathrm{SL}$. B=Dades, $126.4 \mathrm{~mm} \mathrm{SL}$. C=Ziz, 97.1 mm SL. D=Lakhdar, $110.4 \mathrm{~mm} \mathrm{SL}$. E=Miaami, $77.1 \mathrm{~mm} \mathrm{SL}$. F=Isli, $222.6 \mathrm{~mm} \mathrm{SL.} \mathrm{G=Ifni,} 154.9 \mathrm{~mm}$ SL. H=Moulouya, $107.8 \mathrm{~mm} \mathrm{SL.} \mathrm{I=Tensift,} 111.9 \mathrm{~mm} \mathrm{SL}$. All individuals are mature males.

3. Premaxila en las poblaciones atlánticas de Salmo de Marruecos. La población del Dades tiene un proceso superior pequeño e inclinado. La población de Ifni tiene una placa basal más larga que el resto de poblaciones. La población de Isli está fuertemente osificada. A=Melloul, $105.2 \mathrm{~mm} \mathrm{SL}$. B=Dades, $126.4 \mathrm{~mm} \mathrm{SL}$. C=Ziz, $97.1 \mathrm{~mm} \mathrm{SL}$. D=Lakhdar, $110.4 \mathrm{~mm}$ SL. E=Miaami, $77.1 \mathrm{~mm}$ SL. $\mathrm{F}=$ =lsli, $222.6 \mathrm{~mm} \mathrm{SL}$. G=Ifni, $154.9 \mathrm{~mm} \mathrm{SL}$. H=Moulouya, $107.8 \mathrm{~mm} \mathrm{SL}$. I=Tensift, $111.9 \mathrm{~mm}$ SL. Todos los individuos son machos maduros.

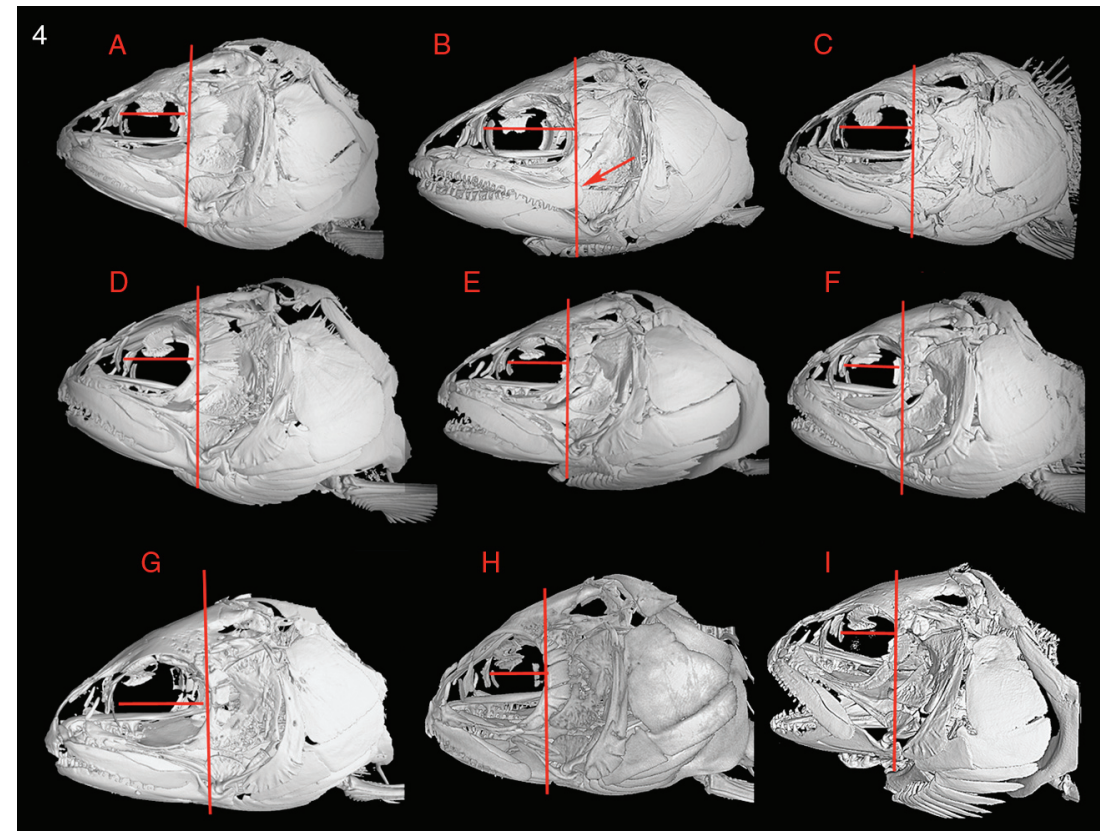

4. Lateral view of the skull in Atlantic Salmo populations from Morocco. Ifni Lake population has the longest maxilla. The orbital space is larger in adult individuals from Ifni Lake and Dades. A=Isli, $222.6 \mathrm{~mm} \mathrm{SL}$. B=Ifni, $154.9 \mathrm{~mm} \mathrm{SL}$. C=Dades, $126.4 \mathrm{~mm}$ SL. D=Miaami, $77.1 \mathrm{~mm} \mathrm{SL}$. E=Melloul, $105.2 \mathrm{~mm} \mathrm{SL.} \mathrm{F=Ziz,} 97.1 \mathrm{~mm} \mathrm{SL}$. G=Lakhdar, $110.4 \mathrm{~mm} \mathrm{SL.} \mathrm{H=Moulouya,} 107.8 \mathrm{~mm}$ $\mathrm{SL}$. I=Tensift, $111.9 \mathrm{~mm} \mathrm{SL}$. All individuals are mature males.

4. Vista lateral del cráneo en las poblaciones atlánticas de Salmo de Marruecos. La población del lago Ifni tiene la maxila más larga. El espacio orbital es más grande en los individuos adultos del Lago ifni y Dades. A=Isli, $222.6 \mathrm{~mm} \mathrm{SL}$. B=Ifni, $154.9 \mathrm{~mm}$ SL. C=Dades, $126.4 \mathrm{~mm}$ SL. D=Miaami, $77.1 \mathrm{~mm} \mathrm{SL}$. E=Melloul, 105.2 mm SL. F=Ziz, 97.1 mm SL. G=Lakhdar, $110.4 \mathrm{~mm} \mathrm{SL.}$ $\mathrm{H}=$ Moulouya, $107.8 \mathrm{~mm} \mathrm{SL}$. I=Tensift, $111.9 \mathrm{~mm}$ SL. Todos los individuos son machos maduros. 


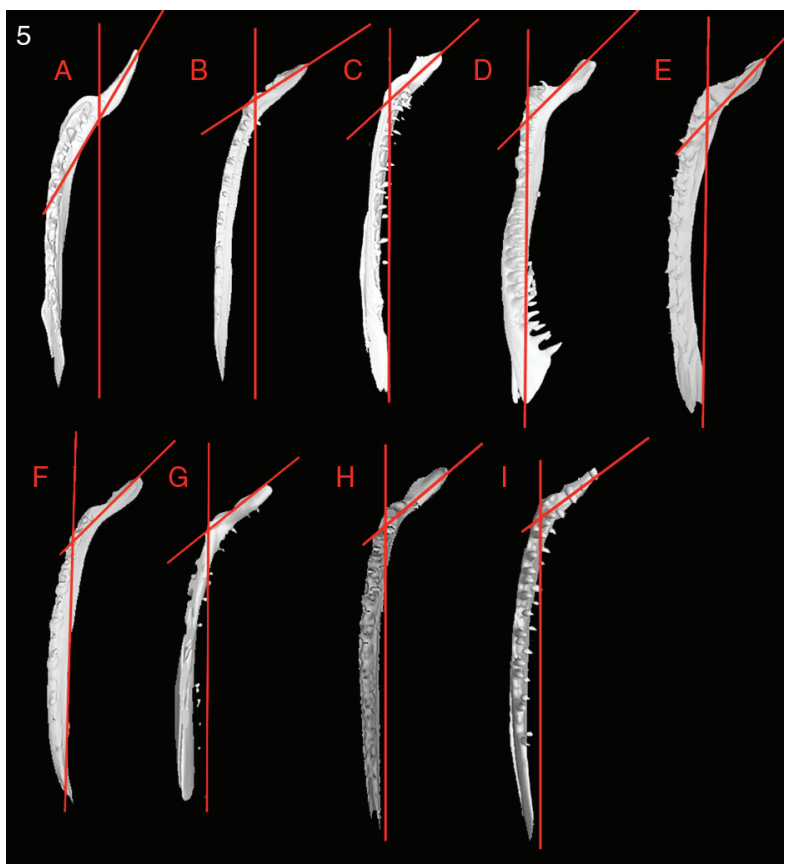

5. Maxilla in Atlantic Salmo populations from Morocco showing the inflection of anterior process from main axis of the maxilla. A=Isli, $222.6 \mathrm{~mm} \mathrm{SL}$. B=Melloul, $105.2 \mathrm{~mm} \mathrm{SL}$. C=Miaami, $77.1 \mathrm{~mm} \mathrm{SL}$. D=Ifni, $154.9 \mathrm{~mm} \mathrm{SL.} \mathrm{E=Ziz,} \mathrm{97.1} \mathrm{mm} \mathrm{SL.} \mathrm{F=Dades,}$ $126.4 \mathrm{~mm}$ SL. G=Lakhdar, $110.4 \mathrm{~mm} \mathrm{SL}$. H=Moulouya, $107.8 \mathrm{~mm} \mathrm{SL}$. I=Tensift, $111.9 \mathrm{~mm} \mathrm{SL}$. All individuals are mature males.

5. Maxila en las poblaciones de Salmo mostrando la inflexión del proceso anterior respecto al eje principal de la maxila. $A=l s l i$, $222.6 \mathrm{~mm}$ SL. B=Melloul, $105.2 \mathrm{~mm} \mathrm{SL}$. C=Miaami, $77.1 \mathrm{~mm} \mathrm{SL}$. D=Ifni, $154.9 \mathrm{~mm}$ SL. E=Ziz, $97.1 \mathrm{~mm} \mathrm{SL.} \mathrm{F=Dades,} 126.4 \mathrm{~mm}$ SL. G=Lakhdar, $110.4 \mathrm{~mm}$ SL. H=Moulouya, $107.8 \mathrm{~mm}$ SL. I=Tensift, $111.9 \mathrm{~mm}$ SL. Todos los individuos son machos maduros. 